\title{
1 A system biology approach identifies candidate drugs to reduce mortality in severely ill COVID-19 patients
}

3 Short title: System biology of critical COVID-19

4 Vinicius M. Fava ${ }^{1,2, \#}$, Mathieu Bourgey ${ }^{3,4, \#}$, Pubudu M. Nawarathna ${ }^{3,4}$, Marianna Orlova ${ }^{1,2,4}$, Pauline

5 Cassart ${ }^{1,2,4}$, Donald C. Vinh ${ }^{1,5}$, Matthew Pellan Cheng ${ }^{1,5,7}$, Guillaume Bourque ${ }^{3,4,6, *}$, Erwin Schurr

$6 \quad 1,2,4,6, *$ David Langlais $4,6,7, *$

$7{ }^{1}$ Infectious Diseases and Immunity in Global Health Program, The Research Institute of the McGill

8 University Health Centre, Montreal, QC, Canada

$9 \quad{ }^{2}$ McGill International TB Centre, McGill University, Montreal, QC, Canada

$10{ }^{3}$ Canadian Centre for Computational Genomics, McGill University, Montréal, QC, Canada.

$11{ }^{4}$ Department for Human Genetics, McGill University Genome Centre, McGill University, Montréal, QC,

12 Canada.

$13{ }^{5}$ Division of Infectious Diseases and Division of Medical Microbiology, McGill University Health

14 Center, McGill University, Montreal, Quebec, Canada

$15{ }^{6}$ McGill University Research Centre on Complex Traits, Montreal, QC, Canada

$16{ }^{7}$ Department of Microbiology and Immunology, McGill University, Montreal, QC, Canada

17 \#, * These authors contributed equally to the work

18 Corresponding authors:

19 David Langlais, PhD, david.langlais@ mcgill.ca

20 Erwin Schurr, PhD, erwin.schurr@mcgill.ca

21 Keywords: SARS-CoV-2, critical COVID-19, scRNA-seq, epigenomics, drug repurposing 
medRxiv preprint doi: https://doi.org/10.1101/2021.09.14.21262309; this version posted September 22, 2021. The copyright holder for this preprint (which was not certified by peer review) is the author/funder, who has granted medRxiv a license to display the preprint in perpetuity.

It is made available under a CC-BY-ND 4.0 International license .

\section{ABSTRACT}

23 Despite the availability of highly efficacious vaccines, Coronavirus Disease 2019 (COVID-19) caused by

24 severe acute respiratory syndrome-related coronavirus-2 (SARS-CoV-2) lacks effective drug treatment

25 which results in a high rate of mortality. To address this therapeutic shortcoming, we applied a system

26 biology approach to the study of patients hospitalized with severe COVID. We show that, at the time of

27 hospital admission, patients who were equivalent on the clinical ordinal scale displayed significant

28 differential monocyte epigenetic and transcriptomic attributes between those who would survive and

29 those who would succumb to COVID-19. We identified mRNA metabolism, RNA splicing, and

30 interferon signaling pathways as key host responses overactivated by patients who would not survive.

31 Those pathways are prime drug targets to reduce mortality of critically ill COVID-19 patients leading us

32 to identify Tacrolimus, Zotatifin, and Nintedanib as three strong candidates for treatment of severely ill

33 patients at the time of hospital admission.

\section{Teaser}

36 Epigenetics distinguishes COVID-19 survivors already at hospital admission: lessons for drug

37 repurposing. 
medRxiv preprint doi: https://doi.org/10.1101/2021.09.14.21262309; this version posted September 22, 2021. The copyright holder for this preprint (which was not certified by peer review) is the author/funder, who has granted medRxiv a license to display the preprint in perpetuity.

It is made available under a CC-BY-ND 4.0 International license .

\section{INTRODUCTION}

Coronavirus Disease 2019 (COVID-19) caused by severe acute respiratory syndrome-related

41 coronavirus-2 (SARS-CoV-2) is characterized by heterogeneous clinical outcomes of infection ranging

42 from absence of clinical symptoms to death. Intense research has resulted in the generation of highly

43 effective vaccines for the prevention of COVID-19 related hospitalization and death (1-5). However,

44 considering the ongoing circulation of the virus, the appearance of new variants with potential for escape

45 of vaccine-induced immunity, the emergence of vaccine breakthroughs and wide-spread vaccine

46 hesitancy, treatment of severely symptomatic COVID-19 patients remains a clinical challenge.

47 Unfortunately, the success of these vaccines has not been paralleled by the development of efficacious

48 drugs for the treatment of COVID-19 and there is an urgent need for effective therapies to treat severely

49 ill COVID-19 patients. Treatment options include antiviral drugs (e.g. remdesivir), which have, so far,

50 demonstrated only a discrete utility in the non-severe setting, or host-directed therapies. Of the latter,

51 dexamethasone is currently recommended for patients who require supplemental oxygen, yet mortality

52 rates remain in excess of $20 \%$ among critically ill patients (6). Therapeutic anticoagulation may reduce

53 mortality in those with mild or moderate disease (7) [ref], while anti-IL6 antibodies (e.g. tocilizumab,

54 sarilumab) can be added to steroid treatment for patients with severe manifestations and inflammation

55 from SARS-CoV-2 (8). Remdesivir is currently approved by the Food and Drug Administration for

56 treatment of COVID-19 patients (9), yet it has not been shown to improve mortality in patients

57 hospitalized with COVID-19 and is not recommended by the WHO (10). A clinical trial in Spain showed

58 that cyclosporine reduced mortality in hospitalized severe COVID-19 patients (11). Since the

59 development of new antiviral drugs is a costly and time-consuming activity, drug repurposing has been

60 the main avenue for discovery of treatment options of COVID-19 patients $(12,13)$.

Efforts of repurposing have focused on scanning key pathways of viral replication and host

62 responses as possible drug targets. Protein-protein or protein-RNA interaction screens have not only

63 provided exciting insight into the basic mechanisms of the SARS-CoV-2 life cycle but have also 
medRxiv preprint doi: https://doi.org/10.1101/2021.09.14.21262309; this version posted September 22, 2021. The copyright holder for this preprint (which was not certified by peer review) is the author/funder, who has granted medRxiv a license to display the preprint in perpetuity.

It is made available under a CC-BY-ND 4.0 International license .

64 identified a multitude of candidate drugs for possible COVID-19 therapy (14-18). Similarly, artificial

65 intelligence and computational modelling have been used to identify candidate repurposed drugs (19-21).

66 Since results of these studies strongly rely on cellular assays, it is difficult to know how these findings

67 will translate to patients. Patient-centric approaches have been focused on high resolution studies of

68 immune processes and host responsiveness of hospitalized patients. These studies have defined key host

69 responses that drive COVID-19 pathology and severity, and have pinpointed the type 1 interferon

70 response as critical regulator of COVID-19 severity (22-28). In addition, these studies have identified

71 single cell features, cell types and gene markers associated with the degree of COVID-19 pathology (28-

72 31). However, these studies were primarily concerned with understanding COVID-19 pathophysiology

73 and generally did not pursue a drug-repurposing strategy.

Given the spectrum of clinical COVID-19 presentations, it seems highly plausible that different

75 drugs are needed for different disease stages. In our study, we have focused on critically ill patients for

76 whom life-saving treatment remains an urgent unmet need. We reasoned that by contrasting critically ill

77 patients who recover with those who perish, we would be able to identify host response pathways

78 segregating between these two outcomes. Such pathways could then be pharmacologically targeted

79 through enhancement- or suppression- based strategies. We enrolled patients with the same severe clinical

80 WHO ordinal scale $(\mathrm{OS}=7)$ at hospital admission and followed these patients for 15 days post admission.

81 Of the seven enrolled patients, three died of COVID-19 while four recovered and were discharged. We

82 contrasted the transcriptome and epigenetic landscape of immune cells of the two patient groups at

83 admission as well as at day 5 and 15 post admission as a follow-up. We found that disease evolution and

84 survival are mainly characterized by changes in cellular composition with relatively modest impact on the

85 transcriptome of key effector cells at later stages of the disease. In contrast, at the time of hospital

86 admission, we detected significant transcriptional changes in key molecular pathways that are associated

87 with epigenetic changes in monocytes. Of importance for the objective of the present study, at a time

88 when the patients were of the same clinical severity, we identified the spliceosome and RNA metabolism 
medRxiv preprint doi: https://doi.org/10.1101/2021.09.14.21262309; this version posted September 22, 2021. The copyright holder for this preprint (which was not certified by peer review) is the author/funder, who has granted medRxiv a license to display the preprint in perpetuity.

It is made available under a CC-BY-ND 4.0 International license .

89 as main targets for repurposed drugs to be deployed at the earliest point of hospitalization of critically ill

90 patients.

$91 \quad$ RESULTS

92 Multi-omics profiling of severely ill hospitalized COVID-19 patients

93 We enrolled seven treatments naïve hospitalized patients with COVID-19 (P1 to P7) at the

94 McGill University Health Centre, Montréal, Québec, Canada (Table 1). Among the seven patients, three

95 were females and four were males. The average time from onset of symptoms to admission was $6 \pm 4.5$

96 (SD) days and the average time from diagnosis to admission was $3 \pm 3.2$ days. At admission, all patients

97 were classified with an OS of 7 in the WHO Clinical Progression Scale (32). Three patients (1 female, 2

98 males) succumbed to the disease at days 8, 16 and 35 post hospital admission. For all patients, peripheral

99 blood mononuclear cells (PBMC) were obtained by phlebotomy followed by standard density gradient

100 centrifugation at three time points: at admission as well as five days (d5) and 15 days (d15) post

101 recruitment (for surviving patients). This design allowed us to follow disease evolution from the same

102 clinical reference point and to identify the epigenomics and cellular factors associated with COVID-19

103 disease evolution (Figure 1). Of importance, the retrospective classification of patients at admission in

104 survivors and non-survivors permitted us to identify early changes in the overall immune status as high

105 value targets for pharmacological intervention to block poor outcomes including death.

106

107

108

109

110

111

\section{Change in cellular components is associated with disease severity}

We used a single-cell RNA sequencing (scRNA-seq) approach to understand the cellular composition and transcriptional status of PBMC following hospitalization and compared the results with those obtained for six healthy controls. Following quality filtering and doublet removal, a total of 105,851 cells were integrated and then clustered using a uniform manifold approximation and projection (UMAP) analysis. All samples were first regrouped into 3 major PBMC populations, namely B cells, Myeloid 
medRxiv preprint doi: https://doi.org/10.1101/2021.09.14.21262309; this version posted September 22, 2021. The copyright holder for this preprint (which was not certified by peer review) is the author/funder, who has granted medRxiv a license to display the preprint in perpetuity.

It is made available under a CC-BY-ND 4.0 International license .

112 cells, and T+NK lymphocytes (Figure 2A). Cells from COVID-19 patients and cells from six healthy

113 controls were homogeneously represented among the 3 clusters (Figure 2B). Clustering was confirmed by

114 the expression of cell specific surface antigens (Figure 2C) and expression of known cell lineage marker

115 genes (Figure 2D). We ran sub-clustering analysis for each of the 3 main lineages to confidently identify

116 sub-populations. The T+NK lineage could be divided into 12 sub-clusters (Suppl. Figure 1), the B cells

117 cluster into 4 sub-clusters (Suppl. Figure 2), and the Myeloid cell cluster into 7 sub-clusters (Suppl.

118 Figure 3), which also included the plasmacytoid dendritic cells (pDC) and some hematopoietic stem and

119 progenitor cells. Cell-type specific gene markers were extracted for every sub-cluster to identify the

120 corresponding cell population.

121 PBMC lineage proportions were compared between patients and controls, as well as classes of

122 patients (Figure 2E-G). In the global comparison, we did not detect significant differences in proportions

123 of T-cells, B-cells and Myeloid cells between healthy controls and all severe COVID-19 samples (Figure

124 2E). Similarly, when patients were retrospectively grouped according to subsequent recovery ("Alive") or

125 death ("Deceased"), we failed to detect significant differences in PBMC lineage proportion for the

126 corresponding day 0 samples (Figure 2F). In contrast, we observed a significant change in major lineage

127 proportions when we pooled all samples according to their clinical status (i.e. Critical vs Moderate

128 according to the OS score) at follow-up (day $5+$ day 15; Figure 2G). This suggested a strong impact of

129 developing COVID-19 severity on PBMC proportions. Critically ill patients showed a significant

130 reduction of T cells $(p$-value $=0.006)$ and a significant increase of Myeloid cells $(p$-value $=0.04)$. These

131 are accounted by the changes in specific cellular subsets, where (i) the decrease in $\mathrm{T}$ cell numbers was

132 driven by a specific reduction of naive $(p$-value $=0.004)$ and central memory $(\mathrm{Tcm} ; p$-value $=0.04) \mathrm{CD} 4+\mathrm{T}$

133 cell populations (Suppl Figure 4A); (ii) B cell sub-populations (Suppl Figure 4B) remained unchanged

134 and confirmed the absence of association with disease severity; and (iii) the increase in Myeloid cells was

135 driven by a specific expansion of CD16+ monocytes ( $p$-value=0.03; Suppl Fig 4C).

\section{Transcriptional expression profile as a marker of the COVID-19 prognosis}



expression (DGE) analyses were conducted for PBMC populations. We excluded the pDC, cDC2 and

139 progenitor populations from this analysis since the total number of identified cells per population was too

140 low $(<300)$ to generate confident results. For comparisons, we employed the same grouping as used for

141 the analysis of lineage proportions, i.e COVID-19 patients "Deceased vs Alive" at day 0, "Critical vs

142 Moderate" at follow-up (see Suppl. Table1 for detailed DGE results per lineage). All significantly

143 differentially expressed genes (adjusted $p$-value $\leq 0.05$ ) were used for GO enrichment analysis, with the

144 over-expressed and lower-expressed genes analyzed separately. The significantly enriched GO terms

145 (adjusted $p$-value $\leq 1 \mathrm{e}-5$ and enriched for at least 5 differentially expressed genes) in at least one cell

146 population were selected and re-examined in every population for the above contrasts. The corresponding

147 results are summarized in the heatmap in Figure 3A and detailed in Suppl. Table 2. Strikingly, despite no

148 differences in WHO clinical score at admission, we observed more transcriptional changes and thus more

149 enriched pathways for the "Decreased vs Alive" comparison at day 0, than for the "Critical vs Moderate"

150 contrast at later time-points (Figure 3A). Based on GO enrichment at admission, we identified three

151 groups of cell populations: high responder cells (HR-cells: CD14+ and intermediate monocytes),

152 moderate responder cells (MR-cells : CD16+ Monocytes, mature B cells, cytotoxic NK CD56dim, and

153 various T cell subsets: NKT-like, Cytotoxic, exhausted (Tex), central memory (Tcm), effector memory

154 (Tem), and Naive CD4+ T cells), and low responder cells (LR-cells: NK CD56bright considered to be

155 high cytokine producers, Activated T cells, $\square \delta$ T, regulatory T cells (Treg), Naive T CD8+ and Naive B

156 cells) with no significant pathway enrichment in the latter cells (Figure 3A, top of heatmap).

158 genes as Modules and calculated Module Scores for each cell population to facilitate comparisons 159 between subject groups. Module Scores were also computed for the "Deceased vs Alive" groups at day 5

160 in order to observe how these transcriptional changes progress along the disease evolution. At admission,

161 the highest Module Score was obtained for genes in "Response to Interferon" identifying this as the most 
162 upregulated term, but only in patients that went on to die from COVID-19 (Figure 3B). In both HR- and

163 MR-cells, this was accompanied by the increased expression of genes involved in "Immune Effector" 164 processes suggesting that exacerbated immune responses and type I interferon signalling in HR- and MR165 cells were linked with poor prognosis for patients (Suppl. Figure 5I). admission are globally more activated than other lymphocyte populations in patients with poor prognosis,

168 with strong induction of genes in the "Immune effector process", "NK cell-mediated immunity", and 169 "Lymphocyte activation" terms (Suppl. Figure 5). Similarly, T and NK cells exhibited increased 170 expression of genes enriched in "Cell junction and adhesion" and "Cell binding and migration" terms. In 171 addition, CD4+ naive $\mathrm{T}$ cells and $\mathrm{Tcm}$ cells displayed strong expression of genes enriched in 172 "Apoptosis", "Response to oxygen levels", "Proteostasis" and "ER stress response" terms. Interestingly, 173 both naive CD4+ and Tcm subpopulations underwent a strong reduction in numbers by day 5 and 15 post 174 admission (Suppl. Figure 4). In monocytes, poor prognosis at admission was also linked with a reduced 175 expression of genes involved in the "Mitochondrial ATP Synthase" (mainly genes of the complex V), the 176 "MHC Complex" and "Ribosome and Translation Initiation" terms. Finally, in mature B cells we 177 observed increased expression of genes enriched in the "B cell activation" term in non-survivors, 178 consistent with a targeted response to SARS-CoV-2 in specific lymphocytes sub-populations. symptoms at follow-up. Overall, transcriptional differences were small and correlated with the "deceased"

181 prognosis at admission. A majority of terms that had shown significant enrichment at admission between

182 "Deceased vs Alive" patients were not detected in this comparison (Figure 3A). However, we still 183 detected significant differences between gene expression Module Scores on day 5 especially in "Response 184 to Interferon", "Immune Effector Process", and "Lymphocyte Activation" terms (Figure 3B; Suppl. 185 Figure 5). Importantly, we noticed that monocytes expressed most of the remaining transcriptional 186 differences between admission and the later stages of the disease. Additionally, the Module Score analysis 
medRxiv preprint doi: https://doi.org/10.1101/2021.09.14.21262309; this version posted September 22, 2021. The copyright holder for this preprint (which was not certified by peer review) is the author/funder, who has granted medRxiv a license to display the preprint in perpetuity.

It is made available under a CC-BY-ND 4.0 International license .

187 of "Deceased vs Alive" patients at follow-up showed lower or null effect size when compared to those

188 observed at admission consistent with the suggestion of a reduced transcriptional impact at later stages of

189 the COVID-19 disease.

The reduced transcriptional differences contrasted with the substantial differences of PBMC

191 lineage proportions that were only observed at later stages of hospitalization. This suggested that

192 variations in transcriptional activity, and the accompanying epigenomics changes, mostly occurred at an

193 early stage of COVID-19 disease, dictating how the disease will evolve in terms of severity and final

194 outcome.

195 The epigenetic profile of CD14+ monocytes correlates with poor prognosis for COVID-19

Given that monocytes had the largest number of transcriptional differences in our scRNA-seq, we

197 sought to analyze their chromatin accessibility using the Assay for Transposase-Accessible Chromatin

198 (ATAC-seq) on CD14+ monocytes enriched from PBMC of hospitalized COVID19 patients over the two

199 weeks follow-up (Figure 1). We observed an increase in the fraction of reads in peaks (FRIP), a surrogate

200 of cell quality and genomic stability, between day 0 and days 5 and 15 (Suppl. Figure 6A). Genomic

201 stability negatively correlated with an increase of the clinical OS, with critically ill cases presenting lower

202 FRIP (Suppl. Figure 6B). The high background resulting from the chromatin instability in patient

203 monocytes restricted the comparison of genomic regions between phenotypic groups. Therefore, we were

204 only able to test for differential accessible chromatin (DAC) in 13398 genomic regions where reads in

205 peaks surpassed the background noise.

206 We contrasted the epigenetic profile of CD14+ monocytes from the "Deceased" patient group

207 with the one from the "Alive" group at day 0 and at follow-up (days $5+15$ ). Of the 13398 chromatin

208 regions tested, 959 were DAC at admission and 407 were DAC at follow-up (Figure 4A; Suppl. Table 3).

209 Interestingly, 222 of the 407 DAC regions (54.5\%) at follow-up overlapped with DAC regions at day 0

210 (Figure 4B and Suppl. Table 3). Among the "Deceased" group, the proportion of regions with sustained 
medRxiv preprint doi: https://doi.org/10.1101/2021.09.14.21262309; this version posted September 22, 2021. The copyright holder for this preprint (which was not certified by peer review) is the author/funder, who has granted medRxiv a license to display the preprint in perpetuity.

It is made available under a CC-BY-ND 4.0 International license .

211 chromatin changes at follow-up was higher for less accessible regions (62.2\%) compared to more

212 accessible regions (32\%; Fisher Exact Test, $p=1.1 \mathrm{e}-7$; Figure 4B). Hence, while chromatin accessibility

213 between the two groups became less pronounced, there was still a trend to maintain accessibility status of

214 DAC regions between admission and follow-up (Figure 4C).

215 To understand the biological mechanisms tagged by epigenetic differences in the "Deceased vs 216 Alive" comparison, we performed DNA binding motif enrichment for DAC regions at admission. We

217 found motifs for seven transcription factors (TFs) enriched in chromatin regions of increased accessibility

218 in "Deceased" patients (Figure 4D). Among these motifs was a set of interferon responsive factors (IRFs)

219 known to regulate interferon responses, and CTCF which is involved in regulating transcription and

220 chromatin architecture (Figure 4D and Suppl. Figure 7). An enrichment of motifs for 39 TFs was

221 observed in regions less accessible in "Deceased" patients. As many of these TFs bind to homologous

222 motifs, we summarized the TFs in groups by similarities in their binding sites (Figure 4D and Suppl.

223 Figure 7). The groups most represented in less accessible regions included transcription factors with Sp1-

224 like and E2F-like binding motifs. These TF families have multiple regulatory functions including cell

225 cycle, differentiation, and chromatin remodeling, but are also associated with immune responses.

226 Potentially as part of feedback loops, TF members of six out of the top eight motif groups had their

227 promoter region also less accessible in "Deceased" patients (Figure 4E, Suppl. Figure 8).

Next, we performed gene ontology and pathway analyses using genes assigned to more open or

229 closed DAC regions at admission and follow-up. Additionally, we stratified the analysis using genes

230 assigned to DAC regions overlapping motifs for the leading TF of each group (Figure 4F). For DAC

231 regions more open at admission, we observed the type-1 interferon response pathway enriched for both

232 IRF-like and CTCF motifs (Figure 4F, Suppl. Table 4). Peaks with CTCF and IRF binding motifs were

233 independent and assigned to different sets of genes that converged in type-1 interferon pathways (Suppl

234 Table 4). Other terms and pathways tagged by more accessible chromatin included mRNA splicing and

235 ATP metabolisms. Interestingly, the ATP metabolism pathways were mostly tagged by peaks with CTCF 
medRxiv preprint doi: https://doi.org/10.1101/2021.09.14.21262309; this version posted September 22, 2021. The copyright holder for this preprint (which was not certified by peer review) is the author/funder, who has granted medRxiv a license to display the preprint in perpetuity.

It is made available under a CC-BY-ND 4.0 International license .

236 motifs, while spliceosome and RNA metabolic pathways were not specific to a TF motif group (Figure

237 4F). Conversely, in accordance with scRNAseq results, RNA transport and proton-transporter for ATP

238 GO terms were more frequently observed in closed chromatin of deceased patients suggesting an unstable

239 RNA metabolism and transport in CD14+ monocytes.

240 Overlap of DAC with severe covid-19 with respiratory failure GWAS.

In a previous genome-wide association study (GWAS) (33), two significant and three suggestive

242 loci were associated with severe COVID-19 with respiratory failure. Out of these five GWAS loci, two

243 overlapped multiple DAC regions for the "Deceased vs Alive" at admission contrast (Figure 5). The

244 overlap between DAC regions and the GWAS loci was significantly not random ( $p=0.01$; Suppl. Figure

245 9). The most significant locus associated with hospitalization in the COVID-19 GWAS encompassed the

246 FYCO1 and LZTFL1 genes on chromosome 3. We observed that the promoter region of these two genes

247 is more accessible in the "Deceased" patient group, with the FYCO1 promoter also maintaining increased

248 accessibility in the follow-up (Figure 5). Interestingly, for the suggestive COVID-19 protective signal

249 observed on chromosome 5, the promoter regions of two flanking genes CEP120 and CSNK1G3 were

250 less accessible in the "Deceased" group at hospital admission and follow-up (Figure 5).

\section{Differences of DNA methylation between patient groups at admission}

252 To further investigate changes in chromatin in CD14+ monocytes at admission, we performed

253 whole genome bisulfite sequencing and compared 26,840,057 CpG loci between the "Deceased vs Alive"

254 patient groups. From the 222,751 differentially methylated loci (DMLs) with a $p$-value $<0.05$ (Suppl.

255 Figure 10A), we discovered 6,259 differentially methylated regions (DMRs; Suppl. Figure 10B).

256 Approximately half $(48.5 \%)$ of the DMRs were hypermethylated in "Deceased" patients. While the

257 majority of DMRs were located in genic and intergenic regions, $7.13 \%$ of DMRs were located in gene

258 promoter regions (Figure 6A). Overall, DMRs were distributed across the genome (Figure 6B). 
medRxiv preprint doi: https://doi.org/10.1101/2021.09.14.21262309; this version posted September 22, 2021. The copyright holder for this preprint (which was not certified by peer review) is the author/funder, who has granted medRxiv a license to display the preprint in perpetuity.

It is made available under a CC-BY-ND 4.0 International license . motif enrichment analysis as implemented for DAC regions and found no significant enrichment at FDR

$261<0.01$. Next, we performed GO-term and pathway analyses based on genes tagged by promoter, distal 262 and gene body DMRs. Using hypermethylated DMRs, located at promoters or tagging distal genes, we

263 observed spliceosome-related pathways and antigen processing and presentation terms significantly 264 enriched in deceased patients (Figure 6C, Suppl. Table 5). In addition, for DMRs in gene body, several 265 pathways including the extracellular matrix organization were significant. Moreover, GO terms and 266 pathways including cytokine secretion and negative regulation of phosphorylation were enriched in gene 267 body and/or distal DMRs. No enrichment was found using hypomethylated DMRs located in the gene 268 body and hypermethylated DMRs located in the gene body combined with distal DMRs.

269 A recent study showed that changes in gene expression in response to infections occur prior to 270 detectable alterations in the methylome (34). Therefore, we hypothesized that methylation changes might 271 increase only at advanced disease stages after the admission. Using the same "Deceased vs Alive" design 272 applied to follow-up samples, we detected 491,208 DMLs ( $p$-value < 0.05) (Suppl. Figure 10C). DMLs 273 were then used to discover a total of 21,516 DMRs (Suppl. Figure 10D). The intersection between the 274 DMRs found at admission and follow-up suggested that approximately $40 \%$ of DMRs were conserved

275 during disease progression (Suppl. Figure 11A). When we conducted gene ontology and pathway 276 analyses for the genes tagged by DMRs at follow-up, we observed 16 (25.6\% from admission) pathways 277 and GO-terms that were already enriched at admission and thus maintained during disease progression, 278 including spliceosome-related pathways and positive regulation of telomere maintenance (Suppl. Figure 279 11B, Suppl. Table 6). Additionally, several pathways and GO-terms including chromatin modifications, 280 RNA localization and modifications were observed exclusively at follow-up. Interestingly, these 281 pathways were already observed altered using DAC regions at admission, suggesting delayed changes at 282 the methylome.

\section{Data integration and identification of candidate drugs}



and gene expression. Specifically, in the "Deceased" patient group the majority of terms tagged by upregulated genes were likewise detected by increased chromatin accessibility (Figure 7A). The concordance of epigenetic and transcriptomic changes was often observed for individual genes. For example, genes such as IFITM2, IFITM3, IFI6 and ISG15 included in the "type-1 interferon signaling" term were upregulated in "Deceased" patients at admission and also displayed increased promoter

290 accessibility (Suppl. Figure 12). As the disease advanced, both transcriptional and chromatin structure 291 differences in the "Deceased vs Alive" contrast attenuated (Suppl. Tables 1 and 3). Significant differences 292 in splicing-related pathways between "Deceased vs Alive" patients were observed at the gene expression, 293 chromatin accessibility and DNA methylation levels (Figure 7A). Moreover, RNA Splicing related terms 294 were among the most significant pathways detected by open DACs and hypermethylated DMRs at 295 follow-up, suggesting that "Deceased" patients could not suppress splicing-related mechanisms (Figure $2964 \mathrm{~F}, 6 \mathrm{C})$. The observation that reduced chromatin accessibility of mRNA splicing-related genes improved 297 survival was also highlighted by corresponding transcriptomic changes (Figure 7A). Hospitalized patients 298 who survived (“Alive” group) showed in monocytes, B, NK and T cells, a significantly lower expression 299 for genes that are part of the mRNA Splicing pathway than patients who died (Figure 7B). Clearly, the 300 identification by different assays of the same differentially activated pathways in cells from COVID-19 301 survivors and decedents implicates these pathways as determinants of prognosis, and thus supports the 302 validity of these pathways as targets for pharmacological intervention.

We searched for existing drugs interacting with pathways and GO terms detected by at least two 304 experimental approaches. We found that Tacrolimus, a calcineurin inhibitor via the immunophilin 305 FKBP1A with properties similar to Cyclosporine, interacted with multiple genes and hubs in the 306 Reactome mRNA Splicing pathway (Figure 7C). By assessing the KEGG drug interactome, we identified 307 Zotatifin, a selective EIF4A inhibitor as an additional repurposed candidate drug targeting the 308 Spliceosome. When evaluating the Reactome interferon signaling pathway and the late phase of HIV life 
medRxiv preprint doi: https://doi.org/10.1101/2021.09.14.21262309; this version posted September 22, 2021. The copyright holder for this preprint (which was not certified by peer review) is the author/funder, who has granted medRxiv a license to display the preprint in perpetuity.

It is made available under a CC-BY-ND 4.0 International license .

309 cycle term, we detected Nintedanib, a triple angiokinase inhibitor used in the treatment of pulmonary

310 fibrosis, as a candidate drug interacting with multiple genes and hubs of these pathways (35). To further

311 assess the interaction network between the candidate drugs and their known biological targets, we

312 intersected OmniPath's protein-protein interaction database with the drugs known biological targets

313 according to DrugBank (Figure 7D). Using genes detected by at least two assays as "proteins of interest",

314 we constructed the interaction network for Tacrolimus and Zotatifin for the mRNA splicing pathway and

315 for Nintedanib for the interferon signaling pathway. Since the 'Deceased' patients exhibited an over-

316 activation of these pathways, drugs interfering with the excessively activated pathways provide promising

317 candidates for further study.

\section{DISCUSSION}

We applied a systems biology approach to study severely ill COVID-19 patients at hospital

320 admission. We hypothesized that a careful characterization of key immune effector cells using single cell

321 transcriptomics and epigenomics would allow identifying host response pathways that lead to recovery or

322 death. We identified monocytes as key effector cells of COVID-19 innate immunity and showed that

323 detrimental host responses are epigenetically poised in the early stages of clinical deterioration. The

324 importance of epigenetic changes of host cells for the viral life cycle had already been suggested by the

325 finding of histone and chromatin modification during SARS-CoV-2 infection (36). Here, we expanded the

326 epigenetics aspect of COVID-19 pathogenesis by applying an in-naturae approach where critically ill

327 patients guided discovery of beneficial and detrimental host response pathways. Combining single cell

328 transcriptomics with the epigenetics analysis, we identified dysregulated responses that constitute

329 promising tractable pathways for pharmacological intervention to reduce mortality of hospitalized

330 COVID-19 patients.

331 Our study design focused on comparing severely ill, hospitalized patients who survived to those

332 who died. Thus, distinguishing itself from previous studies comparing severe COVID-19 patients to 
medRxiv preprint doi: https://doi.org/10.1101/2021.09.14.21262309; this version posted September 22, 2021. The copyright holder for this preprint (which was not certified by peer review) is the author/funder, who has granted medRxiv a license to display the preprint in perpetuity.

It is made available under a CC-BY-ND 4.0 International license .

333 controls or mild patients (37-41); or studies comparing COVID-19 infected patients to other viral diseases

334 (41-43). With our study design we were able to confirm well recognized COVID-19 severity

335 characteristics such as type I IFN dysregulation (44-46); or the systemic upregulation of S100A8/A9

336 genes in monocytes (38). Furthermore, our results showed a strong correlation of PBMC composition

337 with disease progression. Critically ill patients with poor prognosis showed a significant reduction of $\mathrm{T}$

338 cells and a significant increase of monocytes, consistent with previously reported findings in patients

339 suffering from severe COVID-19 $(39,47,48)$. The changes in the proportion of T cells and monocytes we

340 observed were consistent with a declining role of innate immunity (monocytes) and a more prominent

341 role of $\mathrm{T}$ cell immunity at the advanced stage of COVID-19 disease. Intriguingly, in monocytes and $\mathrm{T}$

342 cells, we detected a transcriptional signature at hospital admission which strongly correlated with disease

343 evolution. At hospital admission, naive and central memory CD4+ T cells of patients with poor prognosis

344 strong expression of genes enriched in "Apoptosis", "Response to oxygen levels", "Proteostasis" and "ER

345 stress response" terms which are associated with early stages of cell death $(49,50)$. In monocytes of these

346 patients, we observed a signature of reduced expression of genes involved in "Mitochondrial ATP

347 Synthase" (mainly genes of the complex V), "MHC Complex" and "Ribosome and Translation Initiation"

348 terms. Mitochondrial ATP activity is associated with cell cycle regulation and a decrease of ATP level is

349 associated with cell proliferation (51). Overall, the concordance between the transcriptional signatures at

350 an earlier stage of the disease and the changes of PBMC composition as the disease evolved reinforced

351 the importance of early care treatment decisions to increase COVID-19 patient survival.

The extent of transcriptional variations detected between "Deceased" and "Alive" COVID-19

353 patients at hospital admission, and the continued transcriptional dysregulation with worsening disease at

354 follow-up, supports the pivotal role of monocytes in COVID-19 severity and disease prognosis, as seen

355 by others (52). The key role of monocytes for COVID-19 pathogenesis was also demonstrated by our

356 finding that two of the five GWAS loci for respiratory failure co-localized with chromatin having

357 increased accessibility in monocytes from patients who succumbed to the disease (33). We also showed 
medRxiv preprint doi: https://doi.org/10.1101/2021.09.14.21262309; this version posted September 22, 2021. The copyright holder for this preprint (which was not certified by peer review) is the author/funder, who has granted medRxiv a license to display the preprint in perpetuity.

It is made available under a CC-BY-ND 4.0 International license .

358

359

360

361

362

363

364

365

366

367

368

369

370

371

372

373

374

375

376

377

378

379

380

381

382

that monocyte DNA methylation changes linked with disease severity are associated with genes in the extracellular matrix (ECM) and proteolysis pathways. The implication of the EMC in disease severity could highlight the damage to the structure and function of SARS-CoV-2 infected tissues (53), and the alteration of proteolysis pathways is consistent with the role of host proteolytic enzymes in viral replication and assembly (54). Strikingly, by combining monocyte transcriptomics with chromatin accessibility and DNA methylation, we identified among patients with equivalent clinical severity at admission, activated pathways that tagged those destined to succumb to COVID-19. Most prominent were pathways related to RNA splicing, metabolism and transport, chromatin architecture, and cellular response to interferon. Importantly, while the pathways were identified by a multi-omics approach in CD14+ monocytes, the corresponding transcriptomic changes could be tracked to $\mathrm{B}, \mathrm{T}$, and NK cells, indicating that their contribution is not limited to monocytes.

The functional pathways identified by the combined transcriptomics and epigenetics approach in our study had been previously implicated in COVID-9 pathogenesis. However, our study design pinpointed the differential activity of the pathways at the junction when potentially life-saving clinical treatment decisions for critically ill patients need to be made: when they are admitted to the intensive care unit. The involvement of interferon pathways in the COVID-19 pathogenesis has been well established (44-46). However, while we observed an increased IFN response in deceased patients, we cannot ascribe these abnormal responses as causal to the prognosis; alternatively, they may reflect a host compensatory mechanism (e.g. to uncontrolled viral replication). In contrast, RNA splicing by host cells is a key step of viral replication. SARS-CoV-2 encompasses 16 non-structural proteins (NSP1-NSP16) that are required for the virus to hijack the host transcriptional machinery. Viral NSP16 binds to the U1 and U2 spliceosome complex to negatively regulate host mRNA maturation (55). Additionally, in vitro challenge of Vero E6 cells with SARS-CoV-2 showed increased phosphorylation proteins involved in RNA splicing related pathways, positioning splicing as a critical mechanism of COVID-19 pathogenesis (36). The increased splicing activity observed for deceased patients might benefit viral replication and impair host 
medRxiv preprint doi: https://doi.org/10.1101/2021.09.14.21262309; this version posted September 22, 2021. The copyright holder for this preprint (which was not certified by peer review) is the author/funder, who has granted medRxiv a license to display the preprint in perpetuity.

It is made available under a CC-BY-ND 4.0 International license .

383

384

385

386

387

388

389

390

391

392

393

394

395

396

397

398

399

400

401

402

403

404

405

406

407

immune responses. For instance, splicing disruption was shown to impair IFN responses to SARS-CoV-2 via intron retention (55). We found that genes encoding proteins involved in RNA transport and SRPdependent protein targeting to the membrane were downregulated and less accessible in patients that would succumb to COVID-19. This may reflect the binding of viral NSP8 and NSP9 to the 7SL RNA component of the signal recognition particle (SRP) which interferes with protein trafficking (55).

Our study design further enabled the identification of candidate drugs to reduce mortality among critically ill COVID-19 patients. Using drug-protein and protein-protein interaction databases, we identified three drugs (Tacrolimus, Zotatifin, and Nintedanib) which target pathways that are differentially activated at hospital admission of critically ill patients and that discriminate between eventual survivors and decedents. Tacrolimus and Zotatifin may exert a dual role by interacting with the spliceosome and with NSPs from SARS-CoV-2 (16, 56). Although Tacrolimus is known as a calcineurin inhibitor, it also interacts with U2 RNA components of the spliceosome and was shown to bind to NSP1, a protein that SARS-CoV-2 uses to disrupt protein translation in infected cells (56). Additional support for Tacrolimus as a candidate drug are the observation that Cyclosporin (a molecule with similar properties to Tacrolimus) reduced mortality in hospitalized patients, and the increased survival from COVID-19 in liver transplant recipients treated with tacrolimus $(11,57,58)$. Zotatifin, a member of the class of plant-derived cyclopenta[b]benzofurans compounds named rocaglates, inhibits specifically the RNA helicase eIF4A that is part of the EJC/TREX (exon junction and mRNA transport) complex of the spliceosome. Moreover, Zotatifin was shown in a network encompassing NSP13 and to interact with NSP9 $(16,59)$. The mechanism of action proposed for Zotatifin is via the reduction of viral infectivity and viral protein biogenesis and it is under clinical trial to treat COVID-19 (NCT04632381). Similarly to Zotatifin, the rocaglate CR-1-31-B was shown to potently inhibit SARS-CoV-2 replication at low nanomolar doses in vitro and ex vivo (60). Both Tacrolimus and Zotatifin were among drugs identified by in vitro and in silico models as candidate drugs to treat COVID-19 $(16,17,56)$. Nintedanib is a drug used to treat pulmonary fibrosis. In a small clinical trial, nintedanib did not show significant improvement in 
medRxiv preprint doi: https://doi.org/10.1101/2021.09.14.21262309; this version posted September 22, 2021. The copyright holder for this preprint (which was not certified by peer review) is the author/funder, who has granted medRxiv a license to display the preprint in perpetuity.

It is made available under a CC-BY-ND 4.0 International license .

408 the survival of severe pneumonia induced by COVID-19 (61). However, nintedanib shortened the

409 mechanical ventilation time compared to the placebo group (61). Given that severely ill COVID-19

410 patients may require prolonged respiratory support, nintedanib could be considered as an adjunct therapy

411 with other drugs. In our study, we confirmed the potential of Tacrolimus, Zotatifin, and Nintedanib to

412 treat critically ill COVID-19 patients at hospital admission providing required pre-clinical data to support

413 the testing of these drugs in controlled clinical studies.

\section{METHODS}

415 Patients

Subjects enrolled in the present study were individuals qPCR diagnosed with SARS-CoV-2 who

417 were admitted to the McGill University Health Center (MUHC; Montreal, Quebec, Canada) and recruited

418 to the Canadian Treatments for COVID-19 (CATCO) clinical trial

419 (https://clinicaltrials.gov/ct2/show/NCT04330690). CATCO is a randomized, open-label, controlled trial

420 and represents the Canadian arm of the WHO SOLIDARITY trial. Patient clinical progression was

421 evaluated using the WHO Clinical Progression Scale, which represents a minimal common outcome

422 measure set for COVID-19 clinical research (32). In brief, it provides a measure of illness severity from

423 not infected (ordinal score of 0) to deceased (ordinal score of 10) (32). At the time of recruitment, patients

424 in our cohort were randomized to receive either lopinavir/ritonavir (kaletra), or standard-of-care (Table

425 1). During the conduct of this study, the standard-of-care at our institution consisted solely of

426 supplemental oxygen as required, antithrombotic prophylaxis, and supportive care in the intensive care

427 unit when needed. Based on the outcome of hospitalization, patients were classified as "Deceased" if they

428 died during hospitalization and "Alive" if they were discharged and considered recovered. At admission,

429 all patients were severely ill (OS of 7). To follow disease evolution, disease severity during

430 hospitalization was classified in 3 categories according to the WHO ordinal score: moderate (OS of 4 and

4315 ); severe (OS of 6 or 7) and critical (OS of 8 or 9). Blood samples were collected through standard 
medRxiv preprint doi: https://doi.org/10.1101/2021.09.14.21262309; this version posted September 22, 2021. The copyright holder for this preprint (which was not certified by peer review) is the author/funder, who has granted medRxiv a license to display the preprint in perpetuity.

It is made available under a CC-BY-ND 4.0 International license .

432 venipuncture in standard EDTA blood collection tubes and PBMC were obtained through Ficoll density

433 centrifugation with SepMate tubes (Stemcell Technologies) and kept frozen in 10\% DMSO + 90\% FBS

434 until analysis. The study was approved by the MUHC Research Ethics Board protocol 10-256.

435

scRNA library preparation

Single cell PBMC suspensions were loaded on a Next GEM Chip G (PN-1000120) together with

437 Next GEM Single Cell 3ロ GEM Kit v3.1 (PN-1000121) and single cells were captured on a 10X

438 Genomics Chromium controller. cDNAs were generated following the 10X Genomics protocol. cDNAs

439 were size selected using SPRIselect beads from Beckman Coulter (B23318), and their quality was

440 checked with a Bioanalyzer High Sensitivity DNA Kit from Agilent (5067-4626). One quarter of the total

441 cDNA was used to generate libraries using Chromium Next GEM Single Cell Library Kit (PN-1000121)

442 and barcoded using the Single Index Kit Set A (PN-111213) following the 10X protocol. Libraries were

443 size selected using SPRIselect beads and their quality was checked with the Bioanalyzer High Sensitivity

444 DNA Kit. Libraries size were centered at 450 bp, and paired-end sequenced on NovaSeq 6000 S4 chips.

$A T A C$-seq and WGBS library preparation from CD14+ monocytes

447 Selection Kit II (17858). Viability was assessed with trypan blue staining, and only samples with viability

$448>85 \%$ were used. We then assessed chromatin accessibility using the ATAC-seq method employing

44950,000 CD14+ monocytes $(62,63)$. Briefly, CD14+ monocytes were permeabilized with lysis buffer

450 containing $0.05 \%$ IGEPAL and subsequently obtained nuclei were incubated with Tn5 transposase from

451 Illumina (20034198) for 30 minutes at 37 $\square$ C. Transposed DNAs were purified using Qiagen MinElute

452 PCR Purification Kit and the ATAC-seq libraries were amplified for a total of 8-12 PCR cycles using

453 NEBNext® High-Fidelity 2X PCR Master Mix (M0541) and the Nextera XT Index Kit v2 from Illumina

454 (FC-131-2001, FC-131-2004). Final libraries were purified using sparQ PureMag Beads from QuantaBio

455 (95196-060), and their quality was checked with High Sensitivity DNA Kit from Agilent (5067-4626). 
medRxiv preprint doi: https://doi.org/10.1101/2021.09.14.21262309; this version posted September 22, 2021. The copyright holder for this preprint (which was not certified by peer review) is the author/funder, who has granted medRxiv a license to display the preprint in perpetuity.

It is made available under a CC-BY-ND 4.0 International license .

456 Libraries fragment sizes were mostly distributed between $200 \mathrm{bp}$ and $1000 \mathrm{bp}$. Finally, libraries were 150

457 bp paired-end sequenced on a NovaSeq 6000 S4 chip.

Genomic DNA was extracted from CD14+ monocytes employing the Qiagen blood \& tissue kit

459 (69504). WGBS libraries were prepared using the NxSeq AmpFREE low DNA Library Kit. In summary

460 genomic DNA was sheared using a Covaris E220 instrument. Post shearing cleaning-up was made using

461 AMPure XP beads (0.8x) followed by an End-repair and an A-tailing to allow for adaptor ligation. After

462 ligation, clean up is made using the AMPure XP beads (1x) before proceeding to the size selection

463 (AMPure 0.75x). Another bead clean up (1X AMPure) is realized to remove primer dimers. Bisulfite

464 conversion was made using the EZ-96 DNA Methylation-Gold ${ }^{\mathrm{TM}}$ MagPrep from Zymo Research. The

465 Bisulfite-Converted sample libraries were amplified using LM-PCR followed by a post-amplification

466 clean up (AMPure 1x). Fifteen WGBS libraries were 150 bp paired-end sequenced on a NovaSeq 6000

467 S4 chip.

Single-cell RNA-seq clustering analysis

reads quality

was assessed with

BVAtools

470 (https://bitbucket.org/mugqic/bvatools/src/master/). Cell Ranger v3.0.1 was used for mapping the reads to

471 the hg38 human reference genome assembly, filtering, and counting barcodes and UMIs, resulting in a list

472 of UMI counts for every gene in every cell. To increase the robustness of our data analysis, we also

473 integrated in the analysis 4 external healthy donor PBMC controls ( 3 males and 1 female) available from

474 10X Genomics (3 PBMC CITE-seq and 1 PBMC scRNA-seq). Data from 2 other healthy male donors

475 generated on-site, where also included (64). Based on the barcode and UMI counts, we extracted the

476 summary statistics for the number of genes expressed per cell and for the number of UMIs per cell and

477 applied our cell quality and doublet filtering pipeline (65). Cells with $>20 \%$ mitochondrial genes were

478 excluded. Low-quality cells and doublets were filtered out by excluding cells falling outside the [-1

$479 \mathrm{SD} ;+2.5 \mathrm{SD}]$ interval for UMI and gene count distributions. Events co-expressing either of the cell 
medRxiv preprint doi: https://doi.org/10.1101/2021.09.14.21262309; this version posted September 22, 2021. The copyright holder for this preprint (which was not certified by peer review) is the author/funder, who has granted medRxiv a license to display the preprint in perpetuity.

It is made available under a CC-BY-ND 4.0 International license .

480 specific markers TRBC1, LILRA4, CD14 and CD79A were considered doublets and excluded. The

481 DoubletFinder package was used to identify and filter out the remaining cell doublets (66). Once dead

482 cells and doublets had been removed, the COVID-19 patients and control samples were analyzed jointly

483 with the Seurat v4 R package and cell clustering was performed by the uniform manifold approximation

484 and projection dimension reduction method using the first 25 PCs with the most variable genes, but

485 excluding mitochondrial and ribosomal protein genes $(67,68)$. This analysis identified 4 major

486 populations divided into 22 distinct sub-populations, based on the marker genes for each cluster

487 determined by the MAST approach and validated by TotalSeqB surface protein tagging by CITE-seq

488 controls (69).

Single-cell RNA-seq cellular composition analysis

To estimate the cellular composition, the PBMC lineage proportions were estimated for the 4

491 major populations and the 22 sub-populations. The number of cells composing each lineage inside a

492 particular sample was normalized by the overall number of cells in that sample. The distribution of the

493 sample specific lineage proportion was contrasted overall between Patients and Healthy Controls, at

494 admission between patients retrospectively classified as "Deceased" and "Alive", and at later time points

495 between patients operationally defined as "Moderately" and "Critically" ill. Pairwise t-test comparisons

496 for each contrast in each lineage was used to estimate the impact of COVID-19 on the cellular

497 composition. FDR-adjusted p-values (q-value) were used to assess the significance of these comparisons.

Single-cell RNA-seq differential gene expression (DGE) analysis

500 "Critically vs Moderate" ill at follow-up (days 5 and 15) was evaluated in each lineage using the MAST

501 approach adjusting for Age and Sex covariates (69). Adjusted p-values were estimated using the 502 Benjamini-Hochberg $(\mathrm{BH})$ procedure. Every significant differentially expressed gene (adj-p-value $\leq 0.05)$ 
medRxiv preprint doi: https://doi.org/10.1101/2021.09.14.21262309; this version posted September 22, 2021. The copyright holder for this preprint (which was not certified by peer review) is the author/funder, who has granted medRxiv a license to display the preprint in perpetuity.

It is made available under a CC-BY-ND 4.0 International license .

503 was extracted as down- or up-regulated based on Log2 Fold Change value and used for downstream

504 analysis. All differential expression results are provided in the Suppl. Table1.

\section{Single-cell RNA-seq pathway enrichment analysis}

506 Enrichment analyses for GO biological processes were performed separately on up- and down-

507 regulated DGE genes and for each cell sub-population using the enrichGO function of the clusterProfiler

508 R package v3.13 (70). Enriched results were filtered to keep only GO terms for Biological Processes at

509 level 5. Hierarchical level classification was obtained based on the directed acyclic graph (DAG) defined

510 by the Gene Ontology Consortium provided through the GO.db R Package version v3.13. Additionally,

511 only enrichment results showing a $\mathrm{BH}$ adjusted p-value $\leq 1 \mathrm{e}-5$ supported by at least 5 differentially

512 expressed genes were considered. Enrichment heatmaps were generated based on these selected results

513 using the pheatmap R package v1.0.12. Lineage enrichment clustering was generated using the complete-

514 linkage clustering method integrated in the pheatmap function. All level 5 enrichment results are provided

515 in the Suppl. Table 2 (71).

\section{Single-cell RNA-seq Module Score analysis}

517 Genes contributing to the enrichment of a GO category were extracted to form a transcriptional

518 active module corresponding to that category. Module scores were estimated with the Seurat's

519 AddModuleScore function, using default settings (72). The Module score is determined for each cell by

520 computing the mean transcriptional activity of the genes composing the module minus a mean expression

521 extracted from a set of control genes. Control genes were randomly sampled from bins defined using the

522 observed level of expression for the genes in the module. Module genes composition is available in

523 Suppl. Table 7.

524 ATAC-seq data analyses 
medRxiv preprint doi: https://doi.org/10.1101/2021.09.14.21262309; this version posted September 22, 2021. The copyright holder for this preprint (which was not certified by peer review) is the author/funder, who has granted medRxiv a license to display the preprint in perpetuity.

It is made available under a CC-BY-ND 4.0 International license .

The fifteen ATAC-seq libraries were checked for reads quality and low-quality reads were

526 removed and adaptor sequences trimmed with Cutadapt v1.18 (73). Reads were then aligned to the human

527 genome (hg38) using BWA v0.7.17 default parameters (74). PICARD v2.18.9 was used to mark

528 duplicates and assess the fragment length distribution (75). Next, samtools v1.9 was used to remove reads

529 aligned to mitochondria or alternative contigs (76). AlignmentSieve from DeepTools v3.5.0 was used to

530 filter for unique paired reads (with --samFlagExclude 1804), to remove ENCODE hg38 blacklisted

531 regions and to select fragments between 40 and 2000bp in length (77, 78). Library quality metrics were

532 summarized with MultiQC v1.8 (79). The average fragment size per library was 219bp (SD 16.3bp) with

533 a mean depth of 89.3 (SD 32.8) million fragments. All libraries presented a periodic nucleosome pattern

534 and passed quality control. Chromatin accessibility was determined using MACS2 v2.2.6 callpeak with $q$

535 value $<0.05$ in BAMPE mode (80). We merged overlapping narrow peaks detected in at least two

536 samples with bedtools v2.26 (81). The intersected peak set consisted of 13,892 genomic regions with an

537 average width of 978bp. These peaks were selected for the count-based quantification of accessible

538 chromatin. For each library, featureCounts v1.6.3 was used to count the number of unique fragments

539 overlapping the targeted regions and determine the fraction of reads in peaks (FRIP) (82). We used

540 filterByExpr from edgeR v3.30.3 to select 13,398 peaks with more than ten fragments in $80 \%$ of the 15

541 libraries. The filtered quantification matrix was normalized with the TMM method implemented on

542 calcNormFactors (83). Counts were then scaled and normalized to $\log 2$ count per million (CPM) using

543 limma-voom v3.44.3 (84, 85). The differential accessible chromatin (DAC) analysis for "Deceased vs

544 Alive" at admission and at follow-up was performed with lmFit in limma (84). The linear model was

545 adjusted on the covariates age, sex and FRIP. The log odds of differential accessibility was computed

546 with eBayes (84). We estimated Storey's false discovery rate (FDR) with qualue v2.20.0 package (86).

547 Peaks with FDR $<0.05$ and absolute $\log 2$ fold change $(\log 2 \mathrm{FC})>0.5$ were considered significant DACs.

548 To test if DAC regions were enriched in hospitalized GWAS loci, we used overlapPermTest from

549 regionR v1.20.1 (87). 
medRxiv preprint doi: https://doi.org/10.1101/2021.09.14.21262309; this version posted September 22, 2021. The copyright holder for this preprint (which was not certified by peer review) is the author/funder, who has granted medRxiv a license to display the preprint in perpetuity.

It is made available under a CC-BY-ND 4.0 International license .

ATAC-seq motif enrichment, gene ontology and pathway analysis

To test for enrichment of TF binding motifs in DAC regions, we used the findMotifsGenome

552 function implemented in HOMER v4.11 (88). DAC regions in "Deceased vs Alive" at admision were

553 compared to 50,000 random regions matched by DAC peak mean width and versus non-significant

554 regions (FDR > 50\%). We considered a motif to be significantly enriched if it presented FDR < $1 \%$

555 versus random and FDR $<10 \%$ versus non-significant regions in CD14+ monocytes. TFs were grouped

556 by family and binding motif similarities after manual curation.

$557 \quad$ For GO and pathway analyses we assigned genes to peaks using two approaches. First, peaks

558 were annotated to the genes with a transcription starting site (TSS) located within 5kb from the peak

559 boundary using ChIPSeeker v1.24 (89). Next, we intersected our peak set with the GeneHancer v5 (2019)

560 dataset using mergeByOverlaps from IRange package v2.22.2 (90, 91). By combining the TSS and

561 GeneHancer approaches $76.7 \%$ of the 13,398 tested peaks were assigned to at least one gene. Enrichment

562 analyses for KEGG, Reactome and GO biological processes were performed with clusterProfiler v3.16.0

563 and reactomePA v3.12 (70, 92). For the comparison of Open and Closed DAC regions at admission,

564 pathways and GO terms with FDR $<1 \%$ and at least 10 genes were considered significant. For the

565 follow-up and stratified analyses by motif groups an FDR $<5 \%$ and at least five genes in a pathway were

566 deemed significant.

\section{Data visualization}

569 with a scaling factor based on edgeR's TMM normalization method (78). This approach takes into

570 account only fragments in peaks while also normalizing for library size. Next, SparK v2.6.2 was used to

571 calculate the average base-pair accessibility and standard deviation per group (93). We used

572 removeBatchEffect from limma to calculate the residual $\log 2 \mathrm{CPM}$ after regressing out covariates

573 included in the linear models (84). Volcano plots were produced with ScatterView from MAGeCKFlute

574 v1.8.0 (94). Raincloud, ggpubr and ggplot2 were used to produce the remaining ATAC-seq plots (95, 96). 
medRxiv preprint doi: https://doi.org/10.1101/2021.09.14.21262309; this version posted September 22, 2021. The copyright holder for this preprint (which was not certified by peer review) is the author/funder, who has granted medRxiv a license to display the preprint in perpetuity.

It is made available under a CC-BY-ND 4.0 International license .

575

576

577

578

579

580

581

582

583

584

585

586

587

588

589

590

591

592

593

594

595

596

597

598

\section{DNA methylation Calling and SNP Filtering}

DNA methylation calling was performed with the GenPipes (v3.1.5-beta) "Methyl Seq" pipeline (97). In summary, raw reads were trimmed for quality (quality score $\geq 30$ ) using trimmomatic (v0.36) and to remove sequencing adaptors (73), and then aligned to the human genome hg38 reference genome using Dynamic Read Analysis for Genomics (DRAGEN ${ }^{\mathrm{TM}}$ ) epigenome pipeline (v3.4.5) which utilizes Illumina's DRAGEN ${ }^{\mathrm{TM}}$ Bio-It Platform with the improved and highly optimized mapping algorithms. All samples had a mean genome coverage of at least $18 \times$ (Suppl. Table 8). Duplicate reads were then removed using Picard (v2.9.0) [https://broadinstitute.github.io/picard/] and methylation calls were extracted using the methylation caller included as part of Bismark (v. 0.18.1) (98). CpGs were filtered to remove any position which overlap with a SNP loci, to reduce potential bias introduced by genetic variations. SNP loci were extracted from whole genome sequencing (WGS) libraries from the same patients. GenPipes (v3.1.6-beta) "DNA Seq" pipeline was used to analyze WGS data (97). Raw reads were trimmed for quality (quality score $\geq 30$ ) using skewer 0.2.2 (PMID: 24925680), and then aligned to the human genome hg38 reference genome using BWA 0.7.17 with standard parameters. Alignment refinement was done using GATK (v3.8) and include marking duplicate, indel realignment and base recalibration process. The Haplotype_caller function from GATK (v3.8) was used to call variants (99).

Every SNP found in at least one sample was used to define the set of SNP loci. On average, 860,127 (3.05\%) CpGs were removed from each sample (Suppl. Table 8).

\section{Detection of differentially methylated CpG loci (DML) and differentially methylated regions (DMRs)}

CpG sites with a minimum coverage of two in at least four samples were selected for differential analyses. Methylation raw data were smoothed using a 500-bp smoothing window as a parameter of the BSmooth function implemented in the bsseq Bioconductor package (v. 1.20.0) (100). Smoothed methylation levels of the $\mathrm{CpG}$ sites located on chromosome 21 of every sample were used to perform a principal component analysis to identify confounding factors. Differential methylation was detected using 
medRxiv preprint doi: https://doi.org/10.1101/2021.09.14.21262309; this version posted September 22, 2021. The copyright holder for this preprint (which was not certified by peer review) is the author/funder, who has granted medRxiv a license to display the preprint in perpetuity.

It is made available under a CC-BY-ND 4.0 International license .

599 the R Bioconductor package DSS (v2.32.0) adjusting for patient age and sex (101). The model fitting was

600 done by the DSS function DMLfit.multiFactor. Differentially methylated CpG sites (DML) were

601 extracted using the DSS function DMLtest.multiFactor. Finally, DMLs with p-value $<0.05$ were used to

602 search differentially methylated regions (DMR) using the DSS function callDMR. The direction of the

603 methylation changes (hyper- or hypo-methylation) was defined based on the sum of the test statistics of

604 all DMLs within a DMR as provided by the areaStat value in the results of the callDMR function.

\section{Methylation motif enrichment, gene ontology and pathway analysis}

The analysis of the enrichment of TF motifs in DMRs applied the same procedure as for the

607 looking of TF enrichment in DAC ATAC-seq data. Only DMRs regions in the "Deceased vs Alive"

608 comparison at admission were used to look for TF motifs enrichment. A motif was considered

609 significantly enriched if the FDR was under $1 \%$ when compared to random regions.

610 To detect GO and pathway enrichments, we categorized DMRs into 3 groups based on their 611 genomic location: Gene-body, Promoter and Distal DMRs. Gene-body DMRs are characterized by DMRs

612 containing at least $10 \mathrm{CpGs}$ located inside a gene. Promoter DMRs correspond to DMRs located in

613 between $-5 \mathrm{~kb}$ and the $+1 \mathrm{~kb}$ from a gene transcriptional start site. Due to a high number of DMR located

614 in promoter regions only the top $90 \%$ most differently methylated Promoter DMRs was conserved for the

615 analysis. Finally, Distal DMRs were selected by overlapping Promoter DMRs with the GeneHancer v5

616 (2019) dataset using mergeByOverlaps from IRanges v2.22.2 package, and annotated based on the

617 associated gene (90). For each of the 3 DMR categories, hyper- and hypo-methylated DMRs were

618 analyzed separately. GO Biological Process and KEGG enrichments were detected using the

619 clusterProfiler v3.16.0 package and Reactome enrichment using the reactomePA v1.32.0 package from R.

620 Enrichments were considered significant at FDR $<0.05$ and if the enrichment is supported by at least 5

621 different genes and DMRs $(70,92)$.

\section{Data integration and identification of drug candidates}


medRxiv preprint doi: https://doi.org/10.1101/2021.09.14.21262309; this version posted September 22, 2021. The copyright holder for this preprint (which was not certified by peer review) is the author/funder, who has granted medRxiv a license to display the preprint in perpetuity.

It is made available under a CC-BY-ND 4.0 International license .

624 detected by more than one assay with at least 10 genes and FDR < 5\% (scRNA and ATAC) or 5 genes

625 and FDR $<10 \%$ (DNA methylation) were considered for downstream drug discovery. Due to the

626 hierarchical nature of GO terms and Reactome datasets we selected one term or pathway per hierarchical

627 branch to reduce redundancies for plotting only (full datasets are provided in Suppl. Table 9).

628 To identify drugs interacting with genes and hubs in Reactome pathways we used ReactomeFIViz

629 to access the DrugCentral database in Cytoscape (102-104). The DrugCentral database was created by

630 collecting extensive drug information, including structure, active ingredients, mechanism of action and

631 target interactions for more than 2000 FDA approved drugs. The KEGG database provides a section

632 incorporating drug-pathway interactions, which was accessed to select candidate drugs for the

633 Spliceosome pathway (105). KEGG drugs were curated according to their metabolism, transport,

634 substrates, inhibitors and inducers to be assigned to a given pathway. To build a protein network around

635 the targets for candidate drugs we used OmniPathR protein-protein interaction network and the DBparser

636 packages to access the DrugBank dataset $(106,107)$. We started by extracting the proteins targeted by the

637 candidate drugs in DrugBank. Next, we used genes detected by at least two assays to identify the

638 interaction network starting from the drug target, passing through intermediary proteins, and ending in the

639 "protein of interest". The networks highlight the shortest interaction path between the drug target(s) to the

640 proteins encoded by genes identified in our study. For Zotatifin and Tacrolimus, proteins of interest were

641 encoded by genes part of the mRNA splicing pathway and for Nintedanib, genes in the Interferon

642 Signaling pathway.

\section{Data availability}

The scRNA-seq datasets for the hospitalized COVID-19 patients are available on the European

645 Genome-Phenome Archive, accession number EGAS00001005468. The CITE-seq datasets from healthy

646 controls were retrieved from 10X Genomics. The other healthy controls scRNA-seq datasets were from 
medRxiv preprint doi: https://doi.org/10.1101/2021.09.14.21262309; this version posted September 22, 2021. The copyright holder for this preprint (which was not certified by peer review) is the author/funder, who has granted medRxiv a license to display the preprint in perpetuity. It is made available under a CC-BY-ND 4.0 International license .

647 previously published studies (108). The ATAC-seq and WGBS datasets are available through the

648 International Human Epigenome Consortium (IHEC) data portal (https://epigenomesportal.ca).

\section{Conflict of Interest}

650 None of the authors have any relevant conflicts of interest to disclose. Dr. Cheng reports personal fees

651 from GEn1E Lifesciences (as a member of the scientific advisory board), personal fees from nplex

652 biosciences (as a member of the scientific advisory board), outside the submitted work. He is the co-

653 founder of Kanvas Biosciences and owns equity in the company. In addition, Dr. Cheng has a patent for

654 Methods for detecting tissue damage, graft versus host disease, and infections using cell-free DNA

655 profiling pending. Dr. Cheng and Dr. Vinh have a patent for Methods for assessing the severity and 656 progression of SARS-CoV-2 infections using cell-free DNA pending. 


\section{REFERENCES}

658

659

660

661

662

663

664

665

666

667

668

669

670

671

672

673

674

675

676

677

678

679

680

681

682

683

684

685

686

687

688

689

690

691

692

693

694

695

696

697

1. F. P. Polack, S. J. Thomas, N. Kitchin, J. Absalon, A. Gurtman, S. Lockhart, J. L. Perez, G. Perez Marc, E. D. Moreira, C. Zerbini, R. Bailey, K. A. Swanson, S. Roychoudhury, K. Koury, P. Li, W. V. Kalina, D. Cooper, R. W. Frenck, Jr., L. L. Hammitt, O. Tureci, H. Nell, A. Schaefer, S. Unal, D. B. Tresnan, S. Mather, P. R. Dormitzer, U. Sahin, K. U. Jansen, W. C. Gruber, C. C. T. Group, Safety and Efficacy of the BNT162b2 mRNA Covid-19 Vaccine. N Engl J Med 383, 2603-2615 (2020).

2. L. R. Baden, H. M. El Sahly, B. Essink, K. Kotloff, S. Frey, R. Novak, D. Diemert, S. A. Spector, N. Rouphael, C. B. Creech, J. McGettigan, S. Khetan, N. Segall, J. Solis, A. Brosz, C. Fierro, H. Schwartz, K. Neuzil, L. Corey, P. Gilbert, H. Janes, D. Follmann, M. Marovich, J. Mascola, L. Polakowski, J. Ledgerwood, B. S. Graham, H. Bennett, R. Pajon, C. Knightly, B. Leav, W. Deng, H. Zhou, S. Han, M. Ivarsson, J. Miller, T. Zaks, C. S. Group, Efficacy and Safety of the mRNA-1273 SARS-CoV-2 Vaccine. N Engl J Med 384, 403-416 (2021).

3. M. Voysey, S. A. C. Clemens, S. A. Madhi, L. Y. Weckx, P. M. Folegatti, P. K. Aley, B. Angus, V. L. Baillie, S. L. Barnabas, Q. E. Bhorat, S. Bibi, C. Briner, P. Cicconi, A. M. Collins, R. Colin-Jones, C. L. Cutland, T. C. Darton, K. Dheda, C. J. A. Duncan, K. R. W. Emary, K. J. Ewer, L. Fairlie, S. N. Faust, S. Feng, D. M. Ferreira, A. Finn, A. L. Goodman, C. M. Green, C. A. Green, P. T. Heath, C. Hill, H. Hill, I. Hirsch, S. H. C. Hodgson, A. Izu, S. Jackson, D. Jenkin, C. C. D. Joe, S. Kerridge, A. Koen, G. Kwatra, R. Lazarus, A. M. Lawrie, A. Lelliott, V. Libri, P. J. Lillie, R. Mallory, A. V. A. Mendes, E. P. Milan, A. M. Minassian, A. McGregor, H. Morrison, Y. F. Mujadidi, A. Nana, P. J. O'Reilly, S. D. Padayachee, A. Pittella, E. Plested, K. M. Pollock, M. N. Ramasamy, S. Rhead, A. V. Schwarzbold, N. Singh, A. Smith, R. Song, M. D. Snape, E. Sprinz, R. K. Sutherland, R. Tarrant, E. C. Thomson, M. E. Torok, M. Toshner, D. P. J. Turner, J. Vekemans, T. L. Villafana, M. E. E. Watson, C. J. Williams, A. D. Douglas, A. V. S. Hill, T. Lambe, S. C. Gilbert, A. J. Pollard, C. V. T. G. Oxford, Safety and efficacy of the ChAdOx1 nCoV-19 vaccine (AZD1222) against SARS-CoV-2: an interim analysis of four randomised controlled trials in Brazil, South Africa, and the UK. Lancet 397, 99-111 (2021).

4. M. N. Ramasamy, A. M. Minassian, K. J. Ewer, A. L. Flaxman, P. M. Folegatti, D. R. Owens, M. Voysey, P. K. Aley, B. Angus, G. Babbage, S. Belij-Rammerstorfer, L. Berry, S. Bibi, M. Bittaye, K. Cathie, H. Chappell, S. Charlton, P. Cicconi, E. A. Clutterbuck, R. ColinJones, C. Dold, K. R. W. Emary, S. Fedosyuk, M. Fuskova, D. Gbesemete, C. Green, B. Hallis, M. M. Hou, D. Jenkin, C. C. D. Joe, E. J. Kelly, S. Kerridge, A. M. Lawrie, A. Lelliott, M. N. Lwin, R. Makinson, N. G. Marchevsky, Y. Mujadidi, A. P. S. Munro, M. Pacurar, E. Plested, J. Rand, T. Rawlinson, S. Rhead, H. Robinson, A. J. Ritchie, A. L. Ross-Russell, S. Saich, N. Singh, C. C. Smith, M. D. Snape, R. Song, R. Tarrant, Y. Themistocleous, K. M. Thomas, T. L. Villafana, S. C. Warren, M. E. E. Watson, A. D. Douglas, A. V. S. Hill, T. Lambe, S. C. Gilbert, S. N. Faust, A. J. Pollard, C. V. T. G. Oxford, Safety and immunogenicity of ChAdOx $1 \mathrm{nCoV}-19$ vaccine administered in a prime-boost regimen in young and old adults (COV002): a single-blind, randomised, controlled, phase 2/3 trial. Lancet 396, 1979-1993 (2021). 
5. S. Xia, K. Duan, Y. Zhang, D. Zhao, H. Zhang, Z. Xie, X. Li, C. Peng, Y. Zhang, W. Zhang, Y. Yang, W. Chen, X. Gao, W. You, X. Wang, Z. Wang, Z. Shi, Y. Wang, X. Yang, L. Zhang, L. Huang, Q. Wang, J. Lu, Y. Yang, J. Guo, W. Zhou, X. Wan, C. Wu, W. Wang, S. Huang, J. Du, Z. Meng, A. Pan, Z. Yuan, S. Shen, W. Guo, X. Yang, Effect of an Inactivated Vaccine Against SARS-CoV-2 on Safety and Immunogenicity Outcomes: Interim Analysis of 2 Randomized Clinical Trials. JAMA 324, 951-960 (2020).

6. R. C. Group, P. Horby, W. S. Lim, J. R. Emberson, M. Mafham, J. L. Bell, L. Linsell, N. Staplin, C. Brightling, A. Ustianowski, E. Elmahi, B. Prudon, C. Green, T. Felton, D. Chadwick, K. Rege, C. Fegan, L. C. Chappell, S. N. Faust, T. Jaki, K. Jeffery, A. Montgomery, K. Rowan, E. Juszczak, J. K. Baillie, R. Haynes, M. J. Landray, Dexamethasone in Hospitalized Patients with Covid-19. N Engl J Med 384, 693-704 (2021).

7. A. Investigators, A. C.-a. Investigators, R.-C. Investigators, P. R. Lawler, E. C. Goligher, J. S. Berger, M. D. Neal, B. J. McVerry, J. C. Nicolau, M. N. Gong, M. Carrier, R. S. Rosenson, H. R. Reynolds, A. F. Turgeon, J. Escobedo, D. T. Huang, C. A. Bradbury, B. L. Houston, L. Z. Kornblith, A. Kumar, S. R. Kahn, M. Cushman, Z. McQuilten, A. S. Slutsky, K. S. Kim, A. C. Gordon, B. A. Kirwan, M. M. Brooks, A. M. Higgins, R. J. Lewis, E. Lorenzi, S. M. Berry, L. R. Berry, A. W. Aday, F. Al-Beidh, D. Annane, Y. M. Arabi, D. Aryal, L. Baumann Kreuziger, A. Beane, Z. Bhimani, S. Bihari, H. H. Billett, L. Bond, M. Bonten, F. Brunkhorst, M. Buxton, A. Buzgau, L. A. Castellucci, S. Chekuri, J. T. Chen, A. C. Cheng, T.

Chkhikvadze, B. Coiffard, T. W. Costantini, S. de Brouwer, L. P. G. Derde, M. A. Detry, A. Duggal, V. Dzavik, M. B. Effron, L. J. Estcourt, B. M. Everett, D. A. Fergusson, M. Fitzgerald, R. A. Fowler, J. P. Galanaud, B. T. Galen, S. Gandotra, S. Garcia-Madrona, T. D. Girard, L. C. Godoy, A. L. Goodman, H. Goossens, C. Green, Y. Y. Greenstein, P. L. Gross, N. M. Hamburg, R. Haniffa, G. Hanna, N. Hanna, S. M. Hegde, C. M. Hendrickson, R. D. Hite, A. A. Hindenburg, A. A. Hope, J. M. Horowitz, C. M. Horvat, K. Hudock, B. J. Hunt, M. Husain, R. C. Hyzy, V. N. Iyer, J. R. Jacobson, D. Jayakumar, N. M. Keller, A. Khan, Y. Kim, A. L. Kindzelski, A. J. King, M. M. Knudson, A. E. Kornblith, V. Krishnan, M. E. Kutcher, M. A. Laffan, F. Lamontagne, G. Le Gal, C. M. Leeper, E. S. Leifer, G. Lim, F. G. Lima, K. Linstrum, E. Litton, J. Lopez-Sendon, J. L. Lopez-Sendon Moreno, S. A. Lother, S. Malhotra, M. Marcos, A. Saud Marinez, J. C. Marshall, N. Marten, M. A. Matthay, D. F. McAuley, E. G. McDonald, A. McGlothlin, S. P. McGuinness, S. Middeldorp, S. K. Montgomery, S. C. Moore, R. Morillo Guerrero, P. R. Mouncey, S. Murthy, G. B. Nair, R. Nair, A. D. Nichol, B. Nunez-Garcia, A. Pandey, P. K. Park, R. L. Parke, J. C. Parker, S. Parnia, J. D. Paul, Y. S. Perez Gonzalez, M. Pompilio, M. E. Prekker, J. G. Quigley, N. S. Rost, K. Rowan, F. O. Santos, M. Santos, M. Olombrada Santos, L. Satterwhite, C. T. Saunders, R. E. G. Schutgens, C. W. Seymour, D. M. Siegal, D. G. Silva, Jr., M. ShankarHari, J. P. Sheehan, A. B. Singhal, D. Solvason, S. J. Stanworth, T. Tritschler, A. M. Turner, W. van Bentum-Puijk, F. L. van de Veerdonk, S. van Diepen, G. Vazquez-Grande, L. Wahid, V. Wareham, B. J. Wells, R. J. Widmer, J. G. Wilson, E. Yuriditsky, F. G. Zampieri, D. C. Angus, C. J. McArthur, S. A. Webb, M. E. Farkouh, J. S. Hochman, R. Zarychanski, Therapeutic Anticoagulation with Heparin in Noncritically Ill Patients with Covid-19. N Engl J Med 385, 790-802 (2021). 
8. R.-C. Investigators, A. C. Gordon, P. R. Mouncey, F. Al-Beidh, K. M. Rowan, A. D. Nichol, Y. M. Arabi, D. Annane, A. Beane, W. van Bentum-Puijk, L. R. Berry, Z. Bhimani, M. J. M. Bonten, C. A. Bradbury, F. M. Brunkhorst, A. Buzgau, A. C. Cheng, M. A. Detry, E. J. Duffy, L. J. Estcourt, M. Fitzgerald, H. Goossens, R. Haniffa, A. M. Higgins, T. E. Hills, C. M. Horvat, F. Lamontagne, P. R. Lawler, H. L. Leavis, K. M. Linstrum, E. Litton, E. Lorenzi, J. C. Marshall, F. B. Mayr, D. F. McAuley, A. McGlothlin, S. P. McGuinness, B. J. McVerry, S. K. Montgomery, S. C. Morpeth, S. Murthy, K. Orr, R. L. Parke, J. C. Parker, A. E. Patanwala, V. Pettila, E. Rademaker, M. S. Santos, C. T. Saunders, C. W. Seymour, M. Shankar-Hari, W. I. Sligl, A. F. Turgeon, A. M. Turner, F. L. van de Veerdonk, R. Zarychanski, C. Green, R. J. Lewis, D. C. Angus, C. J. McArthur, S. Berry, S. A. Webb, L. P. G. Derde, Interleukin-6 Receptor Antagonists in Critically III Patients with Covid-19. N Engl J Med 384, 1491-1502 (2021).

9. J. Cohen, K. Kupferschmidt, 'A very, very bad look' for remdesivir. Science 370, 642-643 (2020).

10. W. H. O. S. T. Consortium, H. Pan, R. Peto, A. M. Henao-Restrepo, M. P. Preziosi, V. Sathiyamoorthy, Q. Abdool Karim, M. M. Alejandria, C. Hernandez Garcia, M. P. Kieny, R. Malekzadeh, S. Murthy, K. S. Reddy, M. Roses Periago, P. Abi Hanna, F. Ader, A. M. AlBader, A. Alhasawi, E. Allum, A. Alotaibi, C. A. Alvarez-Moreno, S. Appadoo, A. Asiri, P. Aukrust, A. Barratt-Due, S. Bellani, M. Branca, H. B. C. Cappel-Porter, N. Cerrato, T. S. Chow, N. Como, J. Eustace, P. J. Garcia, S. Godbole, E. Gotuzzo, L. Griskevicius, R. Hamra, M. Hassan, M. Hassany, D. Hutton, I. Irmansyah, L. Jancoriene, J. Kirwan, S. Kumar, P. Lennon, G. Lopardo, P. Lydon, N. Magrini, T. Maguire, S. Manevska, O. Manuel, S. McGinty, M. T. Medina, M. L. Mesa Rubio, M. C. Miranda-Montoya, J. Nel, E. P. Nunes, M. Perola, A. Portoles, M. R. Rasmin, A. Raza, H. Rees, P. P. S. Reges, C. A. Rogers, K. Salami, M. I. Salvadori, N. Sinani, J. A. C. Sterne, M. Stevanovikj, E. Tacconelli, K. A. O. Tikkinen, S. Trelle, H. Zaid, J. A. Rottingen, S. Swaminathan, Repurposed Antiviral Drugs for Covid-19 - Interim WHO Solidarity Trial Results. N Engl J Med 384, 497-511 (2021).

11. P. Guisado-Vasco, S. Valderas-Ortega, M. M. Carralon-Gonzalez, A. Roda-Santacruz, L. Gonzalez-Cortijo, G. Sotres-Fernandez, E. M. Marti-Ballesteros, J. M. Luque-Pinilla, E. Almagro-Casado, F. J. La Coma-Lanuza, R. Barrena-Puertas, E. J. Malo-Benages, M. J. Monforte-Gomez, R. Diez-Munar, E. Merino-Lanza, L. Comeche-Casanova, M. Remirezde-Esparza-Otero, M. Correyero-Plaza, M. Recio-Rodriguez, M. Rodriguez-Lopez, M. D. Sanchez-Manzano, C. Andreu-Vazquez, I. J. Thuissard-Vasallo, J. M. E. Maria-Tome, D. Carnevali-Ruiz, Clinical characteristics and outcomes among hospitalized adults with severe COVID-19 admitted to a tertiary medical center and receiving antiviral, antimalarials, glucocorticoids, or immunomodulation with tocilizumab or cyclosporine: A retrospective observational study (COQUIMA cohort). EClinicalMedicine 28, 100591 (2020).

12. T. U. Singh, S. Parida, M. C. Lingaraju, M. Kesavan, D. Kumar, R. K. Singh, Drug repurposing approach to fight COVID-19. Pharmacol Rep 72, 1479-1508 (2020).

13. O. Indari, S. Jakhmola, E. Manivannan, H. C. Jha, An Update on Antiviral Therapy Against SARS-CoV-2: How Far Have We Come? Front Pharmacol 12, 632677 (2021). 
14. D. Bojkova, K. Klann, B. Koch, M. Widera, D. Krause, S. Ciesek, J. Cinatl, C. Munch, Proteomics of SARS-CoV-2-infected host cells reveals therapy targets. Nature 583, 469472 (2020).

15. A. Karasawa, K. Kubo, Calcium antagonistic effects and the in vitro duration of actions of $\mathrm{KW}-3049$, a new 1,4-dihydropyridine derivative, in isolated canine coronary arteries. Jpn J Pharmacol 47, 35-44 (1988).

16. D. E. Gordon, G. M. Jang, M. Bouhaddou, J. Xu, K. Obernier, K. M. White, M. J. O'Meara, V. V. Rezelj, J. Z. Guo, D. L. Swaney, T. A. Tummino, R. Huttenhain, R. M. Kaake, A. L. Richards, B. Tutuncuoglu, H. Foussard, J. Batra, K. Haas, M. Modak, M. Kim, P. Haas, B. J. Polacco, H. Braberg, J. M. Fabius, M. Eckhardt, M. Soucheray, M. J. Bennett, M. Cakir, M. J. McGregor, Q. Li, B. Meyer, F. Roesch, T. Vallet, A. Mac Kain, L. Miorin, E. Moreno, Z. Z. C. Naing, Y. Zhou, S. Peng, Y. Shi, Z. Zhang, W. Shen, I. T. Kirby, J. E. Melnyk, J. S. Chorba, K. Lou, S. A. Dai, I. Barrio-Hernandez, D. Memon, C. Hernandez-Armenta, J. Lyu, C. J. P. Mathy, T. Perica, K. B. Pilla, S. J. Ganesan, D. J. Saltzberg, R. Rakesh, X. Liu, S. B. Rosenthal, L. Calviello, S. Venkataramanan, J. Liboy-Lugo, Y. Lin, X. P. Huang, Y. Liu, S. A. Wankowicz, M. Bohn, M. Safari, F. S. Ugur, C. Koh, N. S. Savar, Q. D. Tran, D. Shengjuler, S. J. Fletcher, M. C. O' Neal, Y. Cai, J. C. J. Chang, D. J. Broadhurst, S. Klippsten, P. P. Sharp, N. A. Wenzell, D. Kuzuoglu-Ozturk, H. Y. Wang, R. Trenker, J. M. Young, D. A. Cavero, J. Hiatt, T. L. Roth, U. Rathore, A. Subramanian, J. Noack, M. Hubert, R. M. Stroud, A. D. Frankel, O. S. Rosenberg, K. A. Verba, D. A. Agard, M. Ott, M. Emerman, N. Jura, M. von Zastrow, E. Verdin, A. Ashworth, O. Schwartz, C. d'Enfert, S. Mukherjee, M. Jacobson, H. S. Malik, D. G. Fujimori, T. Ideker, C. S. Craik, S. N. Floor, J. S. Fraser, J. D. Gross, A. Sali, B. L. Roth, D. Ruggero, J. Taunton, T. Kortemme, P. Beltrao, M. Vignuzzi, A. Garcia-Sastre, K. M. Shokat, B. K. Shoichet, N. J. Krogan, A SARS-CoV-2 protein interaction map reveals targets for drug repurposing. Nature 583, 459-468 (2020).

17. N. Han, W. Hwang, K. Tzelepis, P. Schmerer, E. Yankova, M. MacMahon, W. Lei, M. K. N, A. Liu, U. Felgenhauer, A. Schuldt, R. Harris, K. Chapman, F. McCaughan, F. Weber, T. Kouzarides, Identification of SARS-CoV-2-induced pathways reveals drug repurposing strategies. Sci Adv 7, (2021).

18. L. Sun, P. Li, X. Ju, J. Rao, W. Huang, L. Ren, S. Zhang, T. Xiong, K. Xu, X. Zhou, M. Gong, E. Miska, Q. Ding, J. Wang, Q. C. Zhang, In vivo structural characterization of the SARS-CoV2 RNA genome identifies host proteins vulnerable to repurposed drugs. Cell 184, 18651883 e1820 (2021).

19. Y. Guo, Y. Zhang, T. Lyu, M. Prosperi, F. Wang, H. Xu, J. Bian, The application of artificial intelligence and data integration in COVID-19 studies: a scoping review. J Am Med Inform Assoc 28, 2050-2067 (2021).

20. Y. Zhou, F. Wang, J. Tang, R. Nussinov, F. Cheng, Artificial intelligence in COVID-19 drug repurposing. Lancet Digit Health 2, e667-e676 (2020).

21. D. Morselli Gysi, I. do Valle, M. Zitnik, A. Ameli, X. Gan, O. Varol, S. D. Ghiassian, J. J. Patten, R. A. Davey, J. Loscalzo, A. L. Barabasi, Network medicine framework for identifying drug-repurposing opportunities for COVID-19. Proc Natl Acad Sci U S A 118, (2021). 
22. M. Liao, Y. Liu, J. Yuan, Y. Wen, G. Xu, J. Zhao, L. Cheng, J. Li, X. Wang, F. Wang, L. Liu, I. Amit, S. Zhang, Z. Zhang, Single-cell landscape of bronchoalveolar immune cells in patients with COVID-19. Nat Med 26, 842-844 (2020).

23. G. Xu, F. Qi, H. Li, Q. Yang, H. Wang, X. Wang, X. Liu, J. Zhao, X. Liao, Y. Liu, L. Liu, S. Zhang, Z. Zhang, The differential immune responses to COVID-19 in peripheral and lung revealed by single-cell RNA sequencing. Cell Discov 6, 73 (2020).

24. C. Lucas, P. Wong, J. Klein, T. B. R. Castro, J. Silva, M. Sundaram, M. K. Ellingson, T. Mao, J. E. Oh, B. Israelow, T. Takahashi, M. Tokuyama, P. Lu, A. Venkataraman, A. Park, S. Mohanty, H. Wang, A. L. Wyllie, C. B. F. Vogels, R. Earnest, S. Lapidus, I. M. Ott, A. J. Moore, M. C. Muenker, J. B. Fournier, M. Campbell, C. D. Odio, A. Casanovas-Massana, I. T. Yale, R. Herbst, A. C. Shaw, R. Medzhitov, W. L. Schulz, N. D. Grubaugh, C. Dela Cruz, S. Farhadian, A. I. Ko, S. B. Omer, A. Iwasaki, Longitudinal analyses reveal immunological misfiring in severe COVID-19. Nature 584, 463-469 (2020).

25. D. Mathew, J. R. Giles, A. E. Baxter, D. A. Oldridge, A. R. Greenplate, J. E. Wu, C. Alanio, L. Kuri-Cervantes, M. B. Pampena, K. D'Andrea, S. Manne, Z. Chen, Y. J. Huang, J. P. Reilly, A. R. Weisman, C. A. G. Ittner, O. Kuthuru, J. Dougherty, K. Nzingha, N. Han, J. Kim, A. Pattekar, E. C. Goodwin, E. M. Anderson, M. E. Weirick, S. Gouma, C. P. Arevalo, M. J. Bolton, F. Chen, S. F. Lacey, H. Ramage, S. Cherry, S. E. Hensley, S. A. Apostolidis, A. C. Huang, L. A. Vella, U. P. C. P. Unit, M. R. Betts, N. J. Meyer, E. J. Wherry, Deep immune profiling of COVID-19 patients reveals distinct immunotypes with therapeutic implications. Science 369, (2020).

26. P. Bastard, L. B. Rosen, Q. Zhang, E. Michailidis, H. H. Hoffmann, Y. Zhang, K. Dorgham, Q. Philippot, J. Rosain, V. Beziat, J. Manry, E. Shaw, L. Haljasmagi, P. Peterson, L. Lorenzo, L. Bizien, S. Trouillet-Assant, K. Dobbs, A. A. de Jesus, A. Belot, A. Kallaste, E. Catherinot, Y. Tandjaoui-Lambiotte, J. Le Pen, G. Kerner, B. Bigio, Y. Seeleuthner, R. Yang, A. Bolze, A. N. Spaan, O. M. Delmonte, M. S. Abers, A. Aiuti, G. Casari, V. Lampasona, L. Piemonti, F. Ciceri, K. Bilguvar, R. P. Lifton, M. Vasse, D. M. Smadja, M. Migaud, J. Hadjadj, B. Terrier, D. Duffy, L. Quintana-Murci, D. van de Beek, L. Roussel, D. C. Vinh, S. G. Tangye, F. Haerynck, D. Dalmau, J. Martinez-Picado, P. Brodin, M. C. Nussenzweig, S. Boisson-Dupuis, C. Rodriguez-Gallego, G. Vogt, T. H. Mogensen, A. J. Oler, J. Gu, P. D. Burbelo, J. I. Cohen, A. Biondi, L. R. Bettini, M. D'Angio, P. Bonfanti, P. Rossignol, J. Mayaux, F. Rieux-Laucat, E. S. Husebye, F. Fusco, M. V. Ursini, L. Imberti, A. Sottini, S. Paghera, E. Quiros-Roldan, C. Rossi, R. Castagnoli, D. Montagna, A. Licari, G. L. Marseglia, X. Duval, J. Ghosn, H. Lab, N.-U. I. R. t. C. Group, C. Clinicians, C.-S. Clinicians, C. G. Imagine, C. C. S. G. French, C. Milieu Interieur, V. C. C. Co, U. M. C. C.-B. Amsterdam, C. H. G. Effort, J. S. Tsang, R. Goldbach-Mansky, K. Kisand, M. S. Lionakis, A. Puel, S. Y. Zhang, S. M. Holland, G. Gorochov, E. Jouanguy, C. M. Rice, A. Cobat, L. D. Notarangelo, L. Abel, H. C. Su, J. L. Casanova, Autoantibodies against type I IFNs in patients with life-threatening COVID-19. Science 370, (2020).

27. P. Bastard, E. Orlova, L. Sozaeva, R. Levy, A. James, M. M. Schmitt, S. Ochoa, M. Kareva, Y. Rodina, A. Gervais, T. Le Voyer, J. Rosain, Q. Philippot, A. L. Neehus, E. Shaw, M. Migaud, L. Bizien, O. Ekwall, S. Berg, G. Beccuti, L. Ghizzoni, G. Thiriez, A. Pavot, C. Goujard, M. L. Fremond, E. Carter, A. Rothenbuhler, A. Linglart, B. Mignot, A. Comte, N. Cheikh, O. Hermine, L. Breivik, E. S. Husebye, S. Humbert, P. Rohrlich, A. Coaquette, F. 
Vuoto, K. Faure, N. Mahlaoui, P. Kotnik, T. Battelino, K. Trebusak Podkrajsek, K. Kisand, E. M. N. Ferre, T. DiMaggio, L. B. Rosen, P. D. Burbelo, M. McIntyre, N. Y. Kann, A. Shcherbina, M. Pavlova, A. Kolodkina, S. M. Holland, S. Y. Zhang, Y. J. Crow, L. D. Notarangelo, H. C. Su, L. Abel, M. S. Anderson, E. Jouanguy, B. Neven, A. Puel, J. L. Casanova, M. S. Lionakis, Preexisting autoantibodies to type I IFNs underlie critical COVID-19 pneumonia in patients with APS-1. J Exp Med 218, (2021).

28. C. Liu, A. J. Martins, W. W. Lau, N. Rachmaninoff, J. Chen, L. Imberti, D. Mostaghimi, D. L. Fink, P. D. Burbelo, K. Dobbs, O. M. Delmonte, N. Bansal, L. Failla, A. Sottini, E. QuirosRoldan, K. L. Han, B. A. Sellers, F. Cheung, R. Sparks, T. W. Chun, S. Moir, M. S. Lionakis, N. C. Consortium, C. Clinicians, C. Rossi, H. C. Su, D. B. Kuhns, J. I. Cohen, L. D. Notarangelo, J. S. Tsang, Time-resolved systems immunology reveals a late juncture linked to fatal COVID-19. Cell 184, 1836-1857 e1822 (2021).

29. P. S. Arunachalam, F. Wimmers, C. K. P. Mok, R. Perera, M. Scott, T. Hagan, N. Sigal, Y. Feng, L. Bristow, O. Tak-Yin Tsang, D. Wagh, J. Coller, K. L. Pellegrini, D. Kazmin, G. Alaaeddine, W. S. Leung, J. M. C. Chan, T. S. H. Chik, C. Y. C. Choi, C. Huerta, M. Paine McCullough, H. Lv, E. Anderson, S. Edupuganti, A. A. Upadhyay, S. E. Bosinger, H. T. Maecker, P. Khatri, N. Rouphael, M. Peiris, B. Pulendran, Systems biological assessment of immunity to mild versus severe COVID-19 infection in humans. Science 369, 12101220 (2020).

30. D. Blanco-Melo, B. E. Nilsson-Payant, W. C. Liu, S. Uhl, D. Hoagland, R. Moller, T. X. Jordan, K. Oishi, M. Panis, D. Sachs, T. T. Wang, R. E. Schwartz, J. K. Lim, R. A. Albrecht, B. R. tenOever, Imbalanced Host Response to SARS-CoV-2 Drives Development of COVID19. Cell 181, 1036-1045 e1039 (2020).

31. M. S. Abers, O. M. Delmonte, E. E. Ricotta, J. Fintzi, D. L. Fink, A. A. A. de Jesus, K. A. Zarember, S. Alehashemi, V. Oikonomou, J. V. Desai, S. W. Canna, B. Shakoory, K. Dobbs, L. Imberti, A. Sottini, E. Quiros-Roldan, F. Castelli, C. Rossi, D. Brugnoni, A. Biondi, L. R. Bettini, M. D'Angio, P. Bonfanti, R. Castagnoli, D. Montagna, A. Licari, G. L. Marseglia, E. F. Gliniewicz, E. Shaw, D. E. Kahle, A. T. Rastegar, M. Stack, K. Myint-Hpu, S. L. Levinson, M. J. DiNubile, D. W. Chertow, P. D. Burbelo, J. I. Cohen, K. R. Calvo, J. S. Tsang, N. C.-Consortium, H. C. Su, J. I. Gallin, D. B. Kuhns, R. Goldbach-Mansky, M. S. Lionakis, L. D. Notarangelo, An immune-based biomarker signature is associated with mortality in COVID-19 patients. JCI Insight 6, (2021).

32. W. H. O.W. G. o. t. C. Characterisation, C.-i. Management of, A minimal common outcome measure set for COVID-19 clinical research. Lancet Infect Dis 20, e192-e197 (2020).

33. G. G. Severe Covid, D. Ellinghaus, F. Degenhardt, L. Bujanda, M. Buti, A. Albillos, P. Invernizzi, J. Fernandez, D. Prati, G. Baselli, R. Asselta, M. M. Grimsrud, C. Milani, F. Aziz, J. Kassens, S. May, M. Wendorff, L. Wienbrandt, F. Uellendahl-Werth, T. Zheng, X. Yi, R. de Pablo, A. G. Chercoles, A. Palom, A. E. Garcia-Fernandez, F. Rodriguez-Frias, A. Zanella, A. Bandera, A. Protti, A. Aghemo, A. Lleo, A. Biondi, A. Caballero-Garralda, A. Gori, A. Tanck, A. Carreras Nolla, A. Latiano, A. L. Fracanzani, A. Peschuck, A. Julia, A. Pesenti, A. Voza, D. Jimenez, B. Mateos, B. Nafria Jimenez, C. Quereda, C. Paccapelo, C. Gassner, C. Angelini, C. Cea, A. Solier, D. Pestana, E. Muniz-Diaz, E. Sandoval, E. M. Paraboschi, E. Navas, F. Garcia Sanchez, F. Ceriotti, F. Martinelli-Boneschi, F. Peyvandi, F. 
Blasi, L. Tellez, A. Blanco-Grau, G. Hemmrich-Stanisak, G. Grasselli, G. Costantino, G. Cardamone, G. Foti, S. Aneli, H. Kurihara, H. ElAbd, I. My, I. Galvan-Femenia, J. Martin, J. Erdmann, J. Ferrusquia-Acosta, K. Garcia-Etxebarria, L. Izquierdo-Sanchez, L. R. Bettini, L. Sumoy, L. Terranova, L. Moreira, L. Santoro, L. Scudeller, F. Mesonero, L. Roade, M. C. Ruhlemann, M. Schaefer, M. Carrabba, M. Riveiro-Barciela, M. E. Figuera Basso, M. G. Valsecchi, M. Hernandez-Tejero, M. Acosta-Herrera, M. D'Angio, M. Baldini, M. Cazzaniga, M. Schulzky, M. Cecconi, M. Wittig, M. Ciccarelli, M. Rodriguez-Gandia, M. Bocciolone, M. Miozzo, N. Montano, N. Braun, N. Sacchi, N. Martinez, O. Ozer, O. Palmieri, P. Faverio, P. Preatoni, P. Bonfanti, P. Omodei, P. Tentorio, P. Castro, P. M. Rodrigues, A. Blandino Ortiz, R. de Cid, R. Ferrer, R. Gualtierotti, R. Nieto, S. Goerg, S. Badalamenti, S. Marsal, G. Matullo, S. Pelusi, S. Juzenas, S. Aliberti, V. Monzani, V. Moreno, T. Wesse, T. L. Lenz, T. Pumarola, V. Rimoldi, S. Bosari, W. Albrecht, W. Peter, M. Romero-Gomez, M. D'Amato, S. Duga, J. M. Banales, J. R. Hov, T. Folseraas, L. Valenti, A. Franke, T. H. Karlsen, Genomewide Association Study of Severe Covid-19 with Respiratory Failure. N Engl J Med 383, 1522-1534 (2020).

34. A. Pacis, F. Mailhot-Leonard, L. Tailleux, H. E. Randolph, V. Yotova, A. Dumaine, J. C. Grenier, L. B. Barreiro, Gene activation precedes DNA demethylation in response to infection in human dendritic cells. Proc Natl Acad Sci U S A 116, 6938-6943 (2019).

35. L. Wollin, E. Wex, A. Pautsch, G. Schnapp, K. E. Hostettler, S. Stowasser, M. Kolb, Mode of action of nintedanib in the treatment of idiopathic pulmonary fibrosis. Eur Respir $\mathrm{J}$ 45, 1434-1445 (2015).

36. M. Bouhaddou, D. Memon, B. Meyer, K. M. White, V. V. Rezelj, M. Correa Marrero, B. J. Polacco, J. E. Melnyk, S. Ulferts, R. M. Kaake, J. Batra, A. L. Richards, E. Stevenson, D. E. Gordon, A. Rojc, K. Obernier, J. M. Fabius, M. Soucheray, L. Miorin, E. Moreno, C. Koh, Q. D. Tran, A. Hardy, R. Robinot, T. Vallet, B. E. Nilsson-Payant, C. Hernandez-Armenta, A. Dunham, S. Weigang, J. Knerr, M. Modak, D. Quintero, Y. Zhou, A. Dugourd, A. Valdeolivas, T. Patil, Q. Li, R. Huttenhain, M. Cakir, M. Muralidharan, M. Kim, G. Jang, B. Tutuncuoglu, J. Hiatt, J. Z. Guo, J. Xu, S. Bouhaddou, C. J. P. Mathy, A. Gaulton, E. J. Manners, E. Felix, Y. Shi, M. Goff, J. K. Lim, T. McBride, M. C. O'Neal, Y. Cai, J. C. J. Chang, D. J. Broadhurst, S. Klippsten, E. De Wit, A. R. Leach, T. Kortemme, B. Shoichet, M. Ott, J. Saez-Rodriguez, B. R. tenOever, R. D. Mullins, E. R. Fischer, G. Kochs, R. Grosse, A. Garcia-Sastre, M. Vignuzzi, J. R. Johnson, K. M. Shokat, D. L. Swaney, P. Beltrao, N. J. Krogan, The Global Phosphorylation Landscape of SARS-CoV-2 Infection. Cell 182, 685712 e619 (2020).

37. A. R. Daamen, P. Bachali, K. A. Owen, K. M. Kingsmore, E. L. Hubbard, A. C. Labonte, R. Robl, S. Shrotri, A. C. Grammer, P. E. Lipsky, Comprehensive transcriptomic analysis of COVID-19 blood, lung, and airway. Sci Rep 11, 7052 (2021).

38. X. Ren, W. Wen, X. Fan, W. Hou, B. Su, P. Cai, J. Li, Y. Liu, F. Tang, F. Zhang, Y. Yang, J. He, W. Ma, J. He, P. Wang, Q. Cao, F. Chen, Y. Chen, X. Cheng, G. Deng, X. Deng, W. Ding, Y. Feng, R. Gan, C. Guo, W. Guo, S. He, C. Jiang, J. Liang, Y. M. Li, J. Lin, Y. Ling, H. Liu, J. Liu, N. Liu, S. Q. Liu, M. Luo, Q. Ma, Q. Song, W. Sun, G. Wang, F. Wang, Y. Wang, X. Wen, Q. Wu, G. Xu, X. Xie, X. Xiong, X. Xing, H. Xu, C. Yin, D. Yu, K. Yu, J. Yuan, B. Zhang, P. Zhang, T. Zhang, J. Zhao, P. Zhao, J. Zhou, W. Zhou, S. Zhong, X. Zhong, S. Zhang, L. Zhu, P. Zhu, B. Zou, J. Zou, Z. Zuo, F. Bai, X. Huang, P. Zhou, Q. Jiang, Z. Huang, J. X. Bei, L. Wei, X. W. 
Bian, X. Liu, T. Cheng, X. Li, P. Zhao, F. S. Wang, H. Wang, B. Su, Z. Zhang, K. Qu, X. Wang, J. Chen, R. Jin, Z. Zhang, COVID-19 immune features revealed by a large-scale single-cell transcriptome atlas. Cell 184, 1895-1913 e1819 (2021).

39. E. Stephenson, G. Reynolds, R. A. Botting, F. J. Calero-Nieto, M. D. Morgan, Z. K. Tuong, K. Bach, W. Sungnak, K. B. Worlock, M. Yoshida, N. Kumasaka, K. Kania, J. Engelbert, B. Olabi, J. S. Spegarova, N. K. Wilson, N. Mende, L. Jardine, L. C. S. Gardner, I. Goh, D. Horsfall, J. McGrath, S. Webb, M. W. Mather, R. G. H. Lindeboom, E. Dann, N. Huang, K. Polanski, E. Prigmore, F. Gothe, J. Scott, R. P. Payne, K. F. Baker, A. T. Hanrath, I. C. D. Schim van der Loeff, A. S. Barr, A. Sanchez-Gonzalez, L. Bergamaschi, F. Mescia, J. L. Barnes, E. Kilich, A. de Wilton, A. Saigal, A. Saleh, S. M. Janes, C. M. Smith, N. Gopee, C. Wilson, P. Coupland, J. M. Coxhead, V. Y. Kiselev, S. van Dongen, J. Bacardit, H. W. King, I. Cambridge Institute of Therapeutic, C.-B. C. Infectious Disease-National Institute of Health Research, A. J. Rostron, A. J. Simpson, S. Hambleton, E. Laurenti, P. A. Lyons, K. B. Meyer, M. Z. Nikolic, C. J. A. Duncan, K. G. C. Smith, S. A. Teichmann, M. R. Clatworthy, J. C. Marioni, B. Gottgens, M. Haniffa, Single-cell multi-omics analysis of the immune response in COVID-19. Nat Med 27, 904-916 (2021).

40. F. Qi, W. Zhang, J. Huang, L. Fu, J. Zhao, Single-Cell RNA Sequencing Analysis of the Immunometabolic Rewiring and Immunopathogenesis of Coronavirus Disease 2019. Front Immunol 12, 651656 (2021).

41. L. Zhu, P. Yang, Y. Zhao, Z. Zhuang, Z. Wang, R. Song, J. Zhang, C. Liu, Q. Gao, Q. Xu, X. Wei, H. X. Sun, B. Ye, Y. Wu, N. Zhang, G. Lei, L. Yu, J. Yan, G. Diao, F. Meng, C. Bai, P. Mao, Y. Yu, M. Wang, Y. Yuan, Q. Deng, Z. Li, Y. Huang, G. Hu, Y. Liu, X. Wang, Z. Xu, P. Liu, Y. Bi, Y. Shi, S. Zhang, Z. Chen, J. Wang, X. Xu, G. Wu, F. S. Wang, G. F. Gao, L. Liu, W. J. Liu, Single-Cell Sequencing of Peripheral Mononuclear Cells Reveals Distinct Immune Response Landscapes of COVID-19 and Influenza Patients. Immunity 53, 685-696 e683 (2020).

42. L. G. Gardinassi, C. O. S. Souza, H. Sales-Campos, S. G. Fonseca, Immune and Metabolic Signatures of COVID-19 Revealed by Transcriptomics Data Reuse. Front Immunol 11, 1636 (2020).

43. M. J. Corley, A. P. S. Pang, K. Dody, P. A. Mudd, B. K. Patterson, H. Seethamraju, Y. Bram, M. J. Peluso, L. Torres, N. S. Iyer, T. A. Premeaux, S. T. Yeung, V. Chandar, A. Borczuk, R. E. Schwartz, T. J. Henrich, S. G. Deeks, J. B. Sacha, L. C. Ndhlovu, Genome-wide DNA methylation profiling of peripheral blood reveals an epigenetic signature associated with severe COVID-19. J Leukoc Biol 110, 21-26 (2021).

44. N. G. Ravindra, M. M. Alfajaro, V. Gasque, N. C. Huston, H. Wan, K. Szigeti-Buck, Y. Yasumoto, A. M. Greaney, V. Habet, R. D. Chow, J. S. Chen, J. Wei, R. B. Filler, B. Wang, G. Wang, L. E. Niklason, R. R. Montgomery, S. C. Eisenbarth, S. Chen, A. Williams, A. Iwasaki, T. L. Horvath, E. F. Foxman, R. W. Pierce, A. M. Pyle, D. van Dijk, C. B. Wilen, Single-cell longitudinal analysis of SARS-CoV-2 infection in human airway epithelium identifies target cells, alterations in gene expression, and cell state changes. PLoS Biol 19, e3001143 (2021).

45. Q. Zhang, P. Bastard, Z. Liu, J. Le Pen, M. Moncada-Velez, J. Chen, M. Ogishi, I. K. D. Sabli, S. Hodeib, C. Korol, J. Rosain, K. Bilguvar, J. Ye, A. Bolze, B. Bigio, R. Yang, A. A. Arias, Q. Zhou, Y. Zhang, F. Onodi, S. Korniotis, L. Karpf, Q. Philippot, M. Chbihi, L. 
1001

1002

1003

1004

1005

1006

1007

1008

1009

1010

1011

1012

1013

1014

1015

1016

1017

1018

1019

1020

1021

1022

1023

1024

1025

1026

1027

1028

1029

1030

1031

1032

1033

1034

1035

1036

1037

1038

1039

1040

1041

1042

1043

1044

Bonnet-Madin, K. Dorgham, N. Smith, W. M. Schneider, B. S. Razooky, H. H. Hoffmann, E. Michailidis, L. Moens, J. E. Han, L. Lorenzo, L. Bizien, P. Meade, A. L. Neehus, A. C. Ugurbil, A. Corneau, G. Kerner, P. Zhang, F. Rapaport, Y. Seeleuthner, J. Manry, C. Masson, Y. Schmitt, A. Schluter, T. Le Voyer, T. Khan, J. Li, J. Fellay, L. Roussel, M. Shahrooei, M. F. Alosaimi, D. Mansouri, H. Al-Saud, F. Al-Mulla, F. Almourfi, S. Z. AlMuhsen, F. Alsohime, S. Al Turki, R. Hasanato, D. van de Beek, A. Biondi, L. R. Bettini, M. D'Angio, P. Bonfanti, L. Imberti, A. Sottini, S. Paghera, E. Quiros-Roldan, C. Rossi, A. J. Oler, M. F. Tompkins, C. Alba, I. Vandernoot, J. C. Goffard, G. Smits, I. Migeotte, F. Haerynck, P. Soler-Palacin, A. Martin-Nalda, R. Colobran, P. E. Morange, S. Keles, F. Colkesen, T. Ozcelik, K. K. Yasar, S. Senoglu, S. N. Karabela, C. Rodriguez-Gallego, G. Novelli, S. Hraiech, Y. Tandjaoui-Lambiotte, X. Duval, C. Laouenan, C.-S. Clinicians, C. Clinicians, C. G. Imagine, C. C. S. G. French, V. C. C. Co, U. M. C. C.-B. Amsterdam, C. H. G. Effort, N.-U. T. C. I. Group, A. L. Snow, C. L. Dalgard, J. D. Milner, D. C. Vinh, T. H. Mogensen, N. Marr, A. N. Spaan, B. Boisson, S. Boisson-Dupuis, J. Bustamante, A. Puel, M. J. Ciancanelli, I. Meyts, T. Maniatis, V. Soumelis, A. Amara, M. Nussenzweig, A. Garcia-Sastre, F. Krammer, A. Pujol, D. Duffy, R. P. Lifton, S. Y. Zhang, G. Gorochov, V. Beziat, E. Jouanguy, V. Sancho-Shimizu, C. M. Rice, L. Abel, L. D. Notarangelo, A. Cobat, H. C. Su, J. L. Casanova, Inborn errors of type I IFN immunity in patients with lifethreatening COVID-19. Science 370, (2020).

46. J. S. Lee, E. C. Shin, The type I interferon response in COVID-19: implications for treatment. Nat Rev Immunol 20, 585-586 (2020).

47. B. D. Pence, Severe COVID-19 and aging: are monocytes the key? Geroscience 42, 10511061 (2020).

48. Z. Chen, E. John Wherry, T cell responses in patients with COVID-19. Nat Rev Immunol 20, 529-536 (2020).

49. S. Lehtonen, T. M. Sonninen, S. Wojciechowski, G. Goldsteins, J. Koistinaho, Dysfunction of Cellular Proteostasis in Parkinson's Disease. Front Neurosci 13, 457 (2019).

50. A. Sendoel, M. O. Hengartner, Apoptotic cell death under hypoxia. Physiology (Bethesda) 29, 168-176 (2014).

51. V. G. Antico Arciuch, M. E. Elguero, J. J. Poderoso, M. C. Carreras, Mitochondrial regulation of cell cycle and proliferation. Antioxid Redox Signal 16, 1150-1180 (2012).

52. M. Merad, J. C. Martin, Pathological inflammation in patients with COVID-19: a key role for monocytes and macrophages. Nat Rev Immunol 20, 355-362 (2020).

53. L. Leng, R. Cao, J. Ma, D. Mou, Y. Zhu, W. Li, L. Lv, D. Gao, S. Zhang, F. Gong, L. Zhao, B. Qiu, H. Xiang, Z. Hu, Y. Feng, Y. Dai, J. Zhao, Z. Wu, H. Li, W. Zhong, Pathological features of COVID-19-associated lung injury: a preliminary proteomics report based on clinical samples. Signal Transduct Target Ther 5, 240 (2020).

54. M. Gioia, C. Ciaccio, P. Calligari, G. De Simone, D. Sbardella, G. Tundo, G. F. Fasciglione, A. Di Masi, D. Di Pierro, A. Bocedi, P. Ascenzi, M. Coletta, Role of proteolytic enzymes in the COVID-19 infection and promising therapeutic approaches. Biochem Pharmacol 182, 114225 (2020).

55. A. K. Banerjee, M. R. Blanco, E. A. Bruce, D. D. Honson, L. M. Chen, A. Chow, P. Bhat, N. Ollikainen, S. A. Quinodoz, C. Loney, J. Thai, Z. D. Miller, A. E. Lin, M. M. Schmidt, D. G. Stewart, D. Goldfarb, G. De Lorenzo, S. J. Rihn, R. M. Voorhees, J. W. Botten, D. 
Majumdar, M. Guttman, SARS-CoV-2 Disrupts Splicing, Translation, and Protein Trafficking to Suppress Host Defenses. Cell 183, 1325-1339 e1321 (2020).

56. J. Carbajo-Lozoya, M. A. Muller, S. Kallies, V. Thiel, C. Drosten, A. von Brunn, Replication of human coronaviruses SARS-CoV, HCoV-NL63 and HCoV-229E is inhibited by the drug FK506. Virus Res 165, 112-117 (2012).

57. L. S. Belli, C. Fondevila, P. A. Cortesi, S. Conti, V. Karam, R. Adam, A. Coilly, B. G. Ericzon, C. Loinaz, V. Cuervas-Mons, M. Zambelli, L. Llado, F. Diaz-Fontenla, F. Invernizzi, D. Patrono, F. Faitot, S. Bhooori, J. Pirenne, G. Perricone, G. Magini, L. Castells, O. Detry, P. M. Cruchaga, J. Colmenero, F. Berrevoet, G. Rodriguez, D. Ysebaert, S. Radenne, H. Metselaar, C. Morelli, L. G. De Carlis, W. G. Polak, C. Duvoux, E.-E. C.-. Registry, Protective Role of Tacrolimus, Deleterious Role of Age and Comorbidities in Liver Transplant Recipients With Covid-19: Results From the ELITA/ELTR Multi-center European Study. Gastroenterology 160, 1151-1163 e1153 (2021).

58. S. Yin, X. Wang, T. Song, Tacrolimus Use and COVID-19 Infection in Patients After Solid Organ Transplantation. Gastroenterology 161, 728-730 e721 (2021).

59. R. F. Service, A call to arms. Science 371, 1092-1095 (2021).

60. C. Muller, W. Obermann, N. Karl, H. G. Wendel, G. Taroncher-Oldenburg, S. Pleschka, R. K. Hartmann, A. Grunweller, J. Ziebuhr, The rocaglate CR-31-B (-) inhibits SARS-CoV-2 replication at non-cytotoxic, low nanomolar concentrations in vitro and ex vivo. Antiviral Res 186, 105012 (2021).

61. Y. Umemura, Y. Mitsuyama, K. Minami, T. Nishida, A. Watanabe, N. Okada, K. Yamakawa, K. Nochioka, S. Fujimi, Efficacy and safety of nintedanib for pulmonary fibrosis in severe pneumonia induced by COVID-19: An interventional study. Int J Infect Dis 108, 454-460 (2021).

62. J. D. Buenrostro, P. G. Giresi, L. C. Zaba, H. Y. Chang, W. J. Greenleaf, Transposition of native chromatin for fast and sensitive epigenomic profiling of open chromatin, DNAbinding proteins and nucleosome position. Nat Methods 10, 1213-1218 (2013).

63. J. D. Buenrostro, B. Wu, H. Y. Chang, W. J. Greenleaf, ATAC-seq: A Method for Assaying Chromatin Accessibility Genome-Wide. Curr Protoc Mol Biol 109, 2129 21-21 2929 (2015).

64. M. Ogishi, R. Yang, C. Aytekin, D. Langlais, M. Bourgey, T. Khan, F. A. Ali, M. Rahman, O. M. Delmonte, M. Chrabieh, P. Zhang, C. Gruber, S. J. Pelham, A. N. Spaan, J. Rosain, W. T. Lei, S. Drutman, M. D. Hellmann, M. K. Callahan, M. Adamow, P. Wong, J. D. Wolchok, G. Rao, C. S. Ma, Y. Nakajima, T. Yaguchi, K. Chamoto, S. C. Williams, J. F. Emile, F. Rozenberg, M. S. Glickman, F. Rapaport, G. Kerner, G. Allington, I. Tezcan, D. Cagdas, F. O. Hosnut, F. Dogu, A. Ikinciogullari, V. K. Rao, L. Kainulainen, V. Beziat, J. Bustamante, S. Vilarinho, R. P. Lifton, B. Boisson, L. Abel, D. Bogunovic, N. Marr, L. D. Notarangelo, S. G. Tangye, T. Honjo, P. Gros, S. Boisson-Dupuis, J. L. Casanova, Inherited PD-1 deficiency underlies tuberculosis and autoimmunity in a child. Nat Med, (2021).

65. V. Beziat, F. Rapaport, J. Hu, M. Titeux, M. Bonnet des Claustres, M. Bourgey, H. Griffin, E. Bandet, C. S. Ma, R. Sherkat, H. Rokni-Zadeh, D. M. Louis, M. Changi-Ashtiani, O. M. Delmonte, T. Fukushima, T. Habib, A. Guennoun, T. Khan, N. Bender, M. Rahman, F. About, R. Yang, G. Rao, C. Rouzaud, J. Li, D. Shearer, K. Balogh, F. Al Ali, M. Ata, S. Dabiri, M. Momenilandi, J. Nammour, M. A. Alyanakian, M. Leruez-Ville, D. Guenat, M. 
Materna, L. Marcot, N. Vladikine, C. Soret, H. Vahidnezhad, L. Youssefian, A. H. Saeidian, J. Uitto, E. Catherinot, S. S. Navabi, M. Zarhrate, D. T. Woodley, M. Jeljeli, T. Abraham, S. Belkaya, L. Lorenzo, J. Rosain, M. Bayat, F. Lanternier, O. Lortholary, F. Zakavi, P. Gros, G. Orth, L. Abel, J. L. Pretet, S. Fraitag, E. Jouanguy, M. M. Davis, S. G. Tangye, L. D. Notarangelo, N. Marr, T. Waterboer, D. Langlais, J. Doorbar, A. Hovnanian, N. Christensen, X. Bossuyt, M. Shahrooei, J. L. Casanova, Humans with inherited T cell CD28 deficiency are susceptible to skin papillomaviruses but are otherwise healthy. Cell 184, 3812-3828 e3830 (2021).

66. C. S. McGinnis, L. M. Murrow, Z. J. Gartner, DoubletFinder: Doublet Detection in SingleCell RNA Sequencing Data Using Artificial Nearest Neighbors. Cell Syst 8, 329-337 e324 (2019).

67. Y. Hao, S. Hao, E. Andersen-Nissen, W. M. Mauck, 3rd, S. Zheng, A. Butler, M. J. Lee, A. J. Wilk, C. Darby, M. Zager, P. Hoffman, M. Stoeckius, E. Papalexi, E. P. Mimitou, J. Jain, A. Srivastava, T. Stuart, L. M. Fleming, B. Yeung, A. J. Rogers, J. M. McElrath, C. A. Blish, R. Gottardo, P. Smibert, R. Satija, Integrated analysis of multimodal single-cell data. Cell 184, 3573-3587 e3529 (2021).

68. E. Becht, L. McInnes, J. Healy, C. A. Dutertre, I. W. H. Kwok, L. G. Ng, F. Ginhoux, E. W. Newell, Dimensionality reduction for visualizing single-cell data using UMAP. Nat Biotechnol, (2018).

69. G. Finak, A. McDavid, M. Yajima, J. Deng, V. Gersuk, A. K. Shalek, C. K. Slichter, H. W. Miller, M. J. McElrath, M. Prlic, P. S. Linsley, R. Gottardo, MAST: a flexible statistical framework for assessing transcriptional changes and characterizing heterogeneity in single-cell RNA sequencing data. Genome Biol 16, 278 (2015).

70. G. Yu, L. G. Wang, Y. Han, Q. Y. He, clusterProfiler: an R package for comparing biological themes among gene clusters. OMICS 16, 284-287 (2012).

71. T. Sorensen, $A$ method of establishing groups of equal amplitude in plant sociology based on similarity of species and its application to analyses of the vegetation on Danish commons (Biologiske Skrifter, 1948), vol. 5.

72. I. Tirosh, B. Izar, S. M. Prakadan, M. H. Wadsworth, 2nd, D. Treacy, J. J. Trombetta, A. Rotem, C. Rodman, C. Lian, G. Murphy, M. Fallahi-Sichani, K. Dutton-Regester, J. R. Lin, O. Cohen, P. Shah, D. Lu, A. S. Genshaft, T. K. Hughes, C. G. Ziegler, S. W. Kazer, A. Gaillard, K. E. Kolb, A. C. Villani, C. M. Johannessen, A. Y. Andreev, E. M. Van Allen, M. Bertagnolli, P. K. Sorger, R. J. Sullivan, K. T. Flaherty, D. T. Frederick, J. Jane-Valbuena, C. H. Yoon, O. Rozenblatt-Rosen, A. K. Shalek, A. Regev, L. A. Garraway, Dissecting the multicellular ecosystem of metastatic melanoma by single-cell RNA-seq. Science 352, 189-196 (2016).

73. A. M. Bolger, M. Lohse, B. Usadel, Trimmomatic: a flexible trimmer for Illumina sequence data. Bioinformatics 30, 2114-2120 (2014).

74. H. Li, R. Durbin, Fast and accurate short read alignment with Burrows-Wheeler transform. Bioinformatics 25, 1754-1760 (2009).

75. Picard Toolkit. Broad Institute, GitHub repository, (2020).

76. H. Li, B. Handsaker, A. Wysoker, T. Fennell, J. Ruan, N. Homer, G. Marth, G. Abecasis, R. Durbin, The Sequence Alignment/Map format and SAMtools. Bioinformatics 25, 20782079 (2009). 
77. H. M. Amemiya, A. Kundaje, A. P. Boyle, The ENCODE Blacklist: Identification of Problematic Regions of the Genome. Sci Rep 9, 9354 (2019).

78. F. Ramirez, D. P. Ryan, B. Gruning, V. Bhardwaj, F. Kilpert, A. S. Richter, S. Heyne, F. Dundar, T. Manke, deepTools2: a next generation web server for deep-sequencing data analysis. Nucleic Acids Res 44, W160-165 (2016).

79. P. Ewels, M. Magnusson, S. Lundin, M. Kaller, MultiQC: summarize analysis results for multiple tools and samples in a single report. Bioinformatics 32, 3047-3048 (2016).

80. Y. Zhang, T. Liu, C. A. Meyer, J. Eeckhoute, D. S. Johnson, B. E. Bernstein, C. Nusbaum, R. M. Myers, M. Brown, W. Li, X. S. Liu, Model-based analysis of ChIP-Seq (MACS). Genome Biol 9, R137 (2008).

81. A. R. Quinlan, I. M. Hall, BEDTools: a flexible suite of utilities for comparing genomic features. Bioinformatics 26, 841-842 (2010).

82. Y. Liao, G. K. Smyth, W. Shi, featureCounts: an efficient general purpose program for assigning sequence reads to genomic features. Bioinformatics 30, 923-930 (2014).

83. M. D. Robinson, D. J. McCarthy, G. K. Smyth, edgeR: a Bioconductor package for differential expression analysis of digital gene expression data. Bioinformatics 26, 139140 (2010).

84. M. E. Ritchie, B. Phipson, D. Wu, Y. Hu, C. W. Law, W. Shi, G. K. Smyth, limma powers differential expression analyses for RNA-sequencing and microarray studies. Nucleic Acids Res 43, e47 (2015).

85. C. W. Law, Y. Chen, W. Shi, G. K. Smyth, voom: Precision weights unlock linear model analysis tools for RNA-seq read counts. Genome Biol 15, R29 (2014).

86. J. D. Storey, A. J. Bass, A. Dabney, D. Robinson, value: Q-value estimation for false discovery rate control. R package version 2.20.0., (2020).

87. B. Gel, A. Diez-Villanueva, E. Serra, M. Buschbeck, M. A. Peinado, R. Malinverni, regioneR: an R/Bioconductor package for the association analysis of genomic regions based on permutation tests. Bioinformatics 32, 289-291 (2016).

88. S. Heinz, C. Benner, N. Spann, E. Bertolino, Y. C. Lin, P. Laslo, J. X. Cheng, C. Murre, H. Singh, C. K. Glass, Simple combinations of lineage-determining transcription factors prime cis-regulatory elements required for macrophage and B cell identities. Mol Cell 38, 576-589 (2010).

89. G. Yu, L. G. Wang, Q. Y. He, ChIPseeker: an R/Bioconductor package for ChIP peak annotation, comparison and visualization. Bioinformatics 31, 2382-2383 (2015).

90. S. Fishilevich, R. Nudel, N. Rappaport, R. Hadar, I. Plaschkes, T. Iny Stein, N. Rosen, A. Kohn, M. Twik, M. Safran, D. Lancet, D. Cohen, GeneHancer: genome-wide integration of enhancers and target genes in GeneCards. Database (Oxford) 2017, (2017).

91. M. Lawrence, W. Huber, H. Pages, P. Aboyoun, M. Carlson, R. Gentleman, M. T. Morgan, V. J. Carey, Software for computing and annotating genomic ranges. PLoS Comput Biol 9, e1003118 (2013).

92. G. Yu, Q. Y. He, ReactomePA: an R/Bioconductor package for reactome pathway analysis and visualization. Mol Biosyst 12, 477-479 (2016).

93. S. Kurtenbach, J. William Harbour, Spark: A Publication-quality NGS Visualization Tool. bioRxiv, 845529 (2019). 
94. B. Wang, M. Wang, W. Zhang, T. Xiao, C. H. Chen, A. Wu, F. Wu, N. Traugh, X. Wang, Z. Li, S. Mei, Y. Cui, S. Shi, J. J. Lipp, M. Hinterndorfer, J. Zuber, M. Brown, W. Li, X. S. Liu, Integrative analysis of pooled CRISPR genetic screens using MAGeCKFlute. Nat Protoc 14, 756-780 (2019).

1180 platform tool for robust data visualization. Wellcome Open Res 4, 63 (2019).

96. H. Wickham, ggplot2: Elegant Graphics for Data Analysis (Springer Publishing Company, Incorporated, 2009), pp. 216.

97. M. Bourgey, R. Dali, R. Eveleigh, K. C. Chen, L. Letourneau, J. Fillon, M. Michaud, M. Caron, J. Sandoval, F. Lefebvre, G. Leveque, E. Mercier, D. Bujold, P. Marquis, P. T. Van, D. Anderson de Lima Morais, J. Tremblay, X. Shao, E. Henrion, E. Gonzalez, P. O. Quirion, B. Caron, G. Bourque, GenPipes: an open-source framework for distributed and scalable genomic analyses. Gigascience 8, (2019).

98. F. Krueger, S. R. Andrews, Bismark: a flexible aligner and methylation caller for BisulfiteSeq applications. Bioinformatics 27, 1571-1572 (2011).

99. A. McKenna, M. Hanna, E. Banks, A. Sivachenko, K. Cibulskis, A. Kernytsky, K. Garimella, D. Altshuler, S. Gabriel, M. Daly, M. A. DePristo, The Genome Analysis Toolkit: a MapReduce framework for analyzing next-generation DNA sequencing data. Genome Res 20, 1297-1303 (2010).

100. K. D. Hansen, B. Langmead, R. A. Irizarry, BSmooth: from whole genome bisulfite sequencing reads to differentially methylated regions. Genome Biol 13, R83 (2012).

101. Y. Park, H. Wu, Differential methylation analysis for BS-seq data under general experimental design. Bioinformatics 32, 1446-1453 (2016).

102. A. S. Blucher, S. K. McWeeney, L. Stein, G. Wu, Visualization of drug target interactions in the contexts of pathways and networks with ReactomeFIViz. F1000Res 8, 908 (2019).

103. S. Avram, C. G. Bologa, J. Holmes, G. Bocci, T. B. Wilson, D. T. Nguyen, R. Curpan, L. Halip, A. Bora, J. J. Yang, J. Knockel, S. Sirimulla, O. Ursu, T. I. Oprea, DrugCentral 2021 supports drug discovery and repositioning. Nucleic Acids Res 49, D1160-D1169 (2021).

104. P. Shannon, A. Markiel, O. Ozier, N. S. Baliga, J. T. Wang, D. Ramage, N. Amin, B. Schwikowski, T. Ideker, Cytoscape: a software environment for integrated models of biomolecular interaction networks. Genome Res 13, 2498-2504 (2003). on genomes, pathways, diseases and drugs. Nucleic Acids Res 45, D353-D361 (2017).

106. D. Turei, T. Korcsmaros, J. Saez-Rodriguez, OmniPath: guidelines and gateway for literature-curated signaling pathway resources. Nat Methods 13, 966-967 (2016). Johnson, C. Li, Z. Sayeeda, N. Assempour, I. lynkkaran, Y. Liu, A. Maciejewski, N. Gale, A. Wilson, L. Chin, R. Cummings, D. Le, A. Pon, C. Knox, M. Wilson, DrugBank 5.0: a major update to the DrugBank database for 2018. Nucleic Acids Res 46, D1074-D1082 (2018).

108. R. Lévy, D. Langlais, V. Béziat, F. Rapaport, G. Rao, T. Lazarov, M. Bourgey, Y. J. Zhou, C. Briand, K. Moriya, F. Ailal, D. T. Avery, J. Markle, A. I. Lim, M. Ogishi, R. Yang, S. Pelham, M. Emam, M. Migaud, C. Deswarte, T. Habib, L. R. Saraiva, E. A. Moussa, A. Guennoun, 
medRxiv preprint doi: https://doi.org/10.1101/2021.09.14.21262309; this version posted September 22, 2021. The copyright holder for this preprint (which was not certified by peer review) is the author/funder, who has granted medRxiv a license to display the preprint in perpetuity.

It is made available under a CC-BY-ND 4.0 International license.

Bousfiha, N. Marr, J. Bustamante, K. Liu, P. Gros, F. Geissmann, S. G. Tangye, J. L.

1221

1222

Casanova, A. Puel, Inherited human c-Rel deficiency disrupts myeloid and lymphoid

1223

immunity to a myriad of infectious agents. J. Clin. Invest 131, e150143 (2021 (in press)). 
medRxiv preprint doi: https://doi.org/10.1101/2021.09.14.21262309; this version posted September 22, 2021. The copyright holder for this preprint (which was not certified by peer review) is the author/funder, who has granted medRxiv a license to display the preprint in perpetuity.

It is made available under a CC-BY-ND 4.0 International license .

\section{ACKNOWLEDGMENTS}

1226 The authors are highly grateful to the study participants for their contribution as well as

1227 acknowledge support received by individuals working at the McGill Genome Center and the McGill

1228 Epigenomics Mapping Center (EMC). This work was supported by a Canada Institute of Health Research

1229 (CIHR) program grant (CEE-151618) for the McGill EMC, which is part of the Canadian Epigenetics,

1230 Environment and Health Research Consortium (CEEHRC) Network and a CIHR Project Grant to DL

1231 (\#168959). DL was also supported by an FRQ-S, Chercheur-Boursier Junior 1 Award and the Canada

1232 Foundation for Innovation John R. Evans Leaders Fund. Work in the lab of ES was supported by a

1233 Foundation grant from CIHR (FDN-143332) and a Canada Foundation for Innovation John R. Evans

1234 Leaders Fund award. GB is supported by a Canada Research Chair Tier 1 award, a FRQ-S, Distinguished

1235 Research Scholar award and the Canadian Center for Computational Genomics (C3G) is supported by a

1236 Genome Canada Genome Technology Platform grant. MPC was supported by a CIHR grant during the

1237 conduct of the study. The work was also supported by an award from the McGill Interdisciplinary

1238 Initiative in Infection and Immunity (MI4) to MPC, MB, GB, and ES. This research was enabled in part

1239 by support provided by Calcul Quebec and Compute Canada (www.computecanada.ca). 
medRxiv preprint doi: https://doi.org/10.1101/2021.09.14.21262309; this version posted September 22, 2021. The copyright holder for this preprint (which was not certified by peer review) is the author/funder, who has granted medRxiv a license to display the preprint in perpetuity.

It is made available under a CC-BY-ND 4.0 International license.

\section{FIGURES AND TABLES}

Table 1: Patient demographics

\begin{tabular}{|c|c|c|c|c|c|c|c|c|c|c|}
\hline \multirow{2}{*}{ Subject } & \multirow{2}{*}{ Sex } & \multirow{2}{*}{$\begin{array}{l}\text { Age } \\
\text { range }\end{array}$} & \multirow{2}{*}{$\begin{array}{c}\text { COVID-19 } \\
\text { treatment }\end{array}$} & \multicolumn{5}{|c|}{ Ordinal scale } & \multirow{2}{*}{$\begin{array}{c}\text { Days } \\
\text { hospitalized }\end{array}$} & \multirow{2}{*}{$\begin{array}{r}\text { Status at } \\
\text { discharge }\end{array}$} \\
\hline & & & & Day 0 & Day 3 & Day 5 & Day 8 & Day 15 & & \\
\hline P1 & Female & $45-50$ & SOC & 7 & 7 & 6 & 7 & 4 & 7 & alive \\
\hline $\mathrm{P} 2$ & Male & $45-50$ & SOC & 7 & 7 & 8 & 5 & 4 & 27 & alive \\
\hline P3 & Female & $30-35$ & Kaletra & 7 & 9 & 8 & - & - & 9 & deceased \\
\hline P4 & Male & $45-50$ & SOC & 7 & 9 & 9 & 8 & 9 & 35 & deceased \\
\hline P5 & Male & $40-45$ & SOC & 7 & 4 & 6 & 4 & 4 & 30 & alive \\
\hline P6 & Female & $75-80$ & SOC & 7 & 5 & 4 & 4 & 4 & 22 & alive \\
\hline P7 & Male & $90-95$ & SOC & 7 & 6 & 6 & 6 & 6 & 16 & deceased \\
\hline
\end{tabular}

SOC, standard-of-care. For precise dates, comorbidities and more detailed patient information contact the corresponding author. 

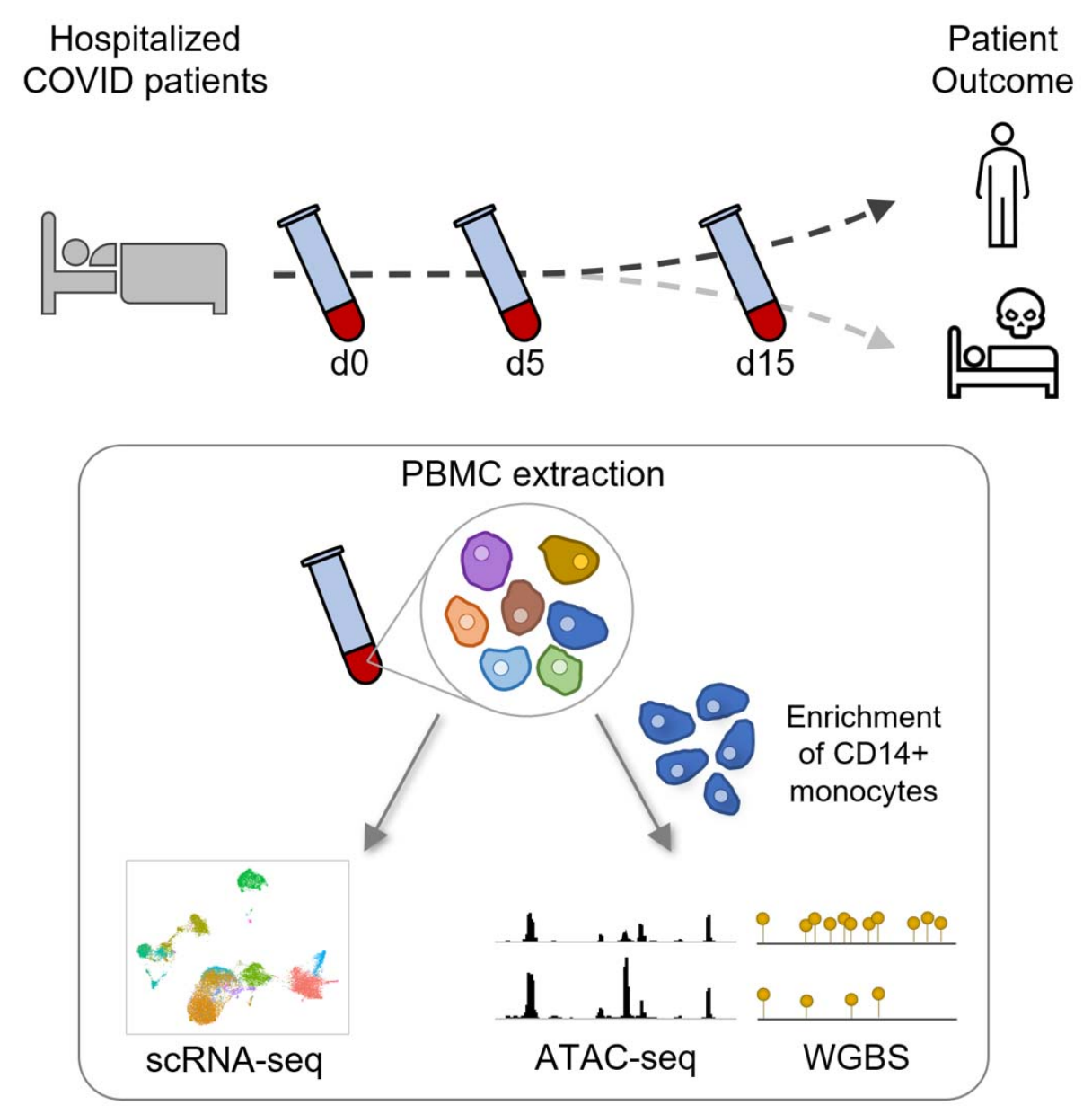

\section{Figure 1. Study design summary.}

1246 Blood samples were collected from severely ill COVID-19 patients at the time of hospitalization (d0) and

1247 at follow-ups (days 5 and 15) during their stay in the critical care unit. PBMC were isolated from the

1248 blood and captured for scRNA-seq. CD14+ monocytes were also enriched from PBMC for epigenetic 1249 analyses: chromatin accessibility by ATAC-seq and DNA methylation by WGBS. 
medRxiv preprint doi: https://doi.org/10.1101/2021.09.14.21262309; this version posted September 22, 2021. The copyright holder for this preprint (which was not certified by peer review) is the author/funder, who has granted medRxiv a license to display the preprint in perpetuity.

It is made available under a CC-BY-ND 4.0 International license .

A

B

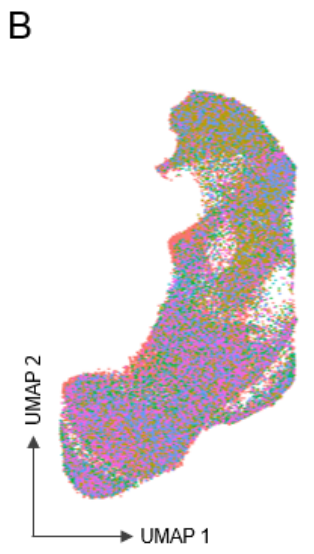

- pDC \& progenitors

- B cells

- T + NK cells

- Myeloid cells
E

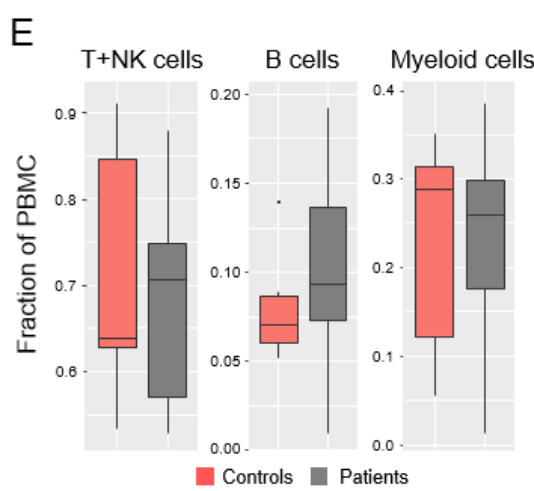

1250

F

Admission Deceased

- Admission Alive

- Follow-up Critical

- Follow-up Severe

- Follow-up Moderate

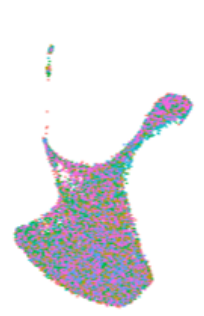

C
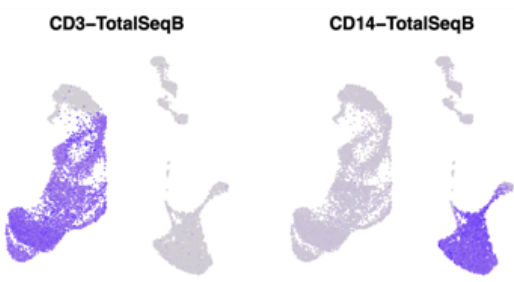

CD19-TotalSeqB

5

$\mathrm{D}$

CD3G

CD14
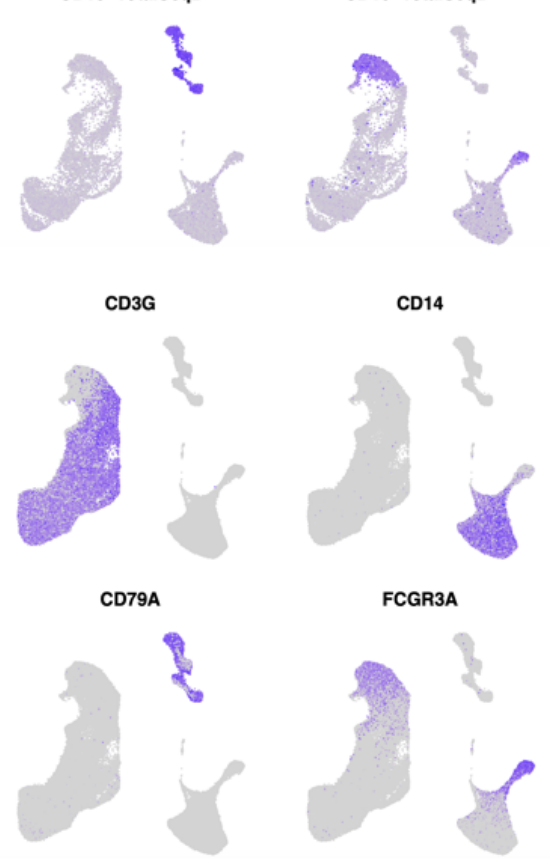

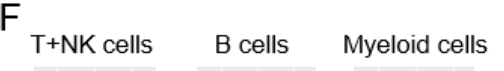
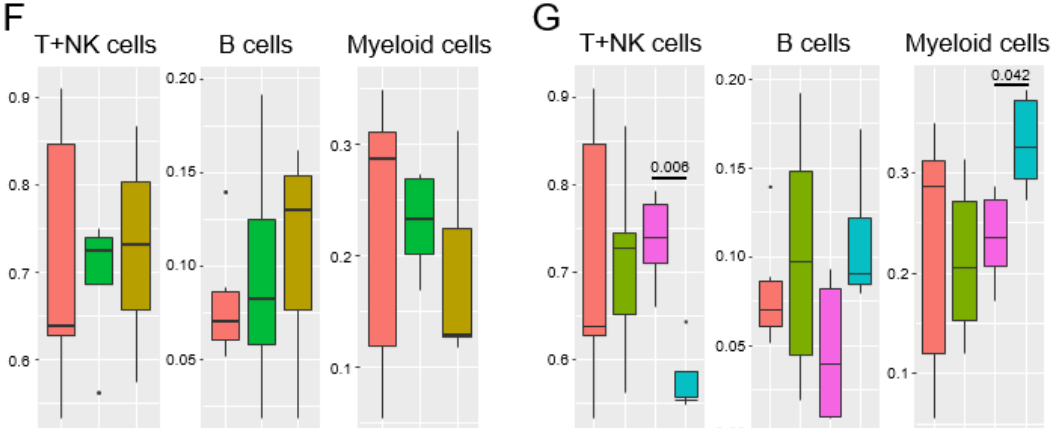

Controls admission Alive Admission Deceased

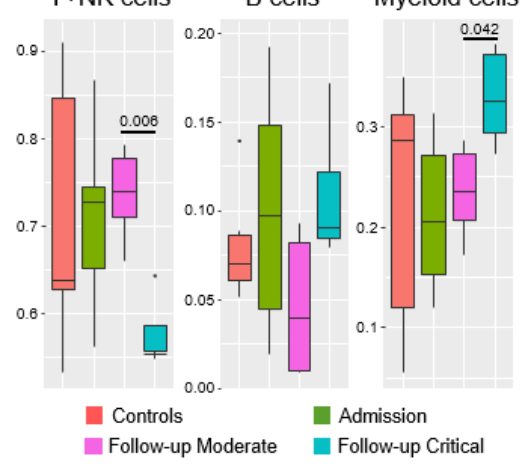

1251 Figure 2. Cellular composition of PBMC from severely ill hospitalized COVID-19 patients and

1252 controls.

1253 (A) UMAP visualization of PBMC from 7 COVID-19 patients (18 samples obtained at days 0, 5 and 15

1254 of admission) and 6 healthy controls identified four major PBMC lineages. (B) Cells are coloured

1255 according to the clinical classification of COVID-19 patients and healthy controls. (C) Visualisation of

1256 four cell surface lineage specific markers across cell clusters using TotalSeqB antibodies on control 
medRxiv preprint doi: https://doi.org/10.1101/2021.09.14.21262309; this version posted September 22, 2021. The copyright holder for this preprint (which was not certified by peer review) is the author/funder, who has granted medRxiv a license to display the preprint in perpetuity. It is made available under a CC-BY-ND 4.0 International license .

1257 samples reveals T cells (CD3), CD14+ monocytes (CD14), B cells (CD19), and CD16+ and NK cells

1258 (CD16). (D) Cells are coloured according to the expression of the lineage marker genes $C D 3 G$ (T cells),

1259 CD14 (CD14+ monocytes), CD79A (B cells) and FCGR3A (CD16+ monocytes and NK cells). (E-G) Box

1260 and whisker plots for the proportion of cells in each major lineage compared to the overall number of

1261 cells in the sample for T+NK, B and Myeloid cells among clinical groups. The PBMC lineage proportions

1262 are shown for healthy control samples (red) versus (E) all COVID-19 samples (cyan); (F) samples

1263 collected from COVID-19 patients at admission and retrospectively classified as Deceased (blue) or Alive

1264 (green); and (G) samples at days 5 and 15 for patients classified as displaying Moderate (cyan) or Critical

1265 (purple) clinical symptoms.

1266 Q-values for pairwise t-test comparisons (Admission - Deceased vs Alive; Follow-up - Critical vs

1267 Moderate) are provided when significant. 
medRxiv preprint doi: https://doi.org/10.1101/2021.09.14.21262309; this version posted September 22, 2021. The copyright holder for this preprint (which was not certified by peer review) is the author/funder, who has granted medRxiv a license to display the preprint in perpetuity.

It is made available under a CC-BY-ND 4.0 International license .

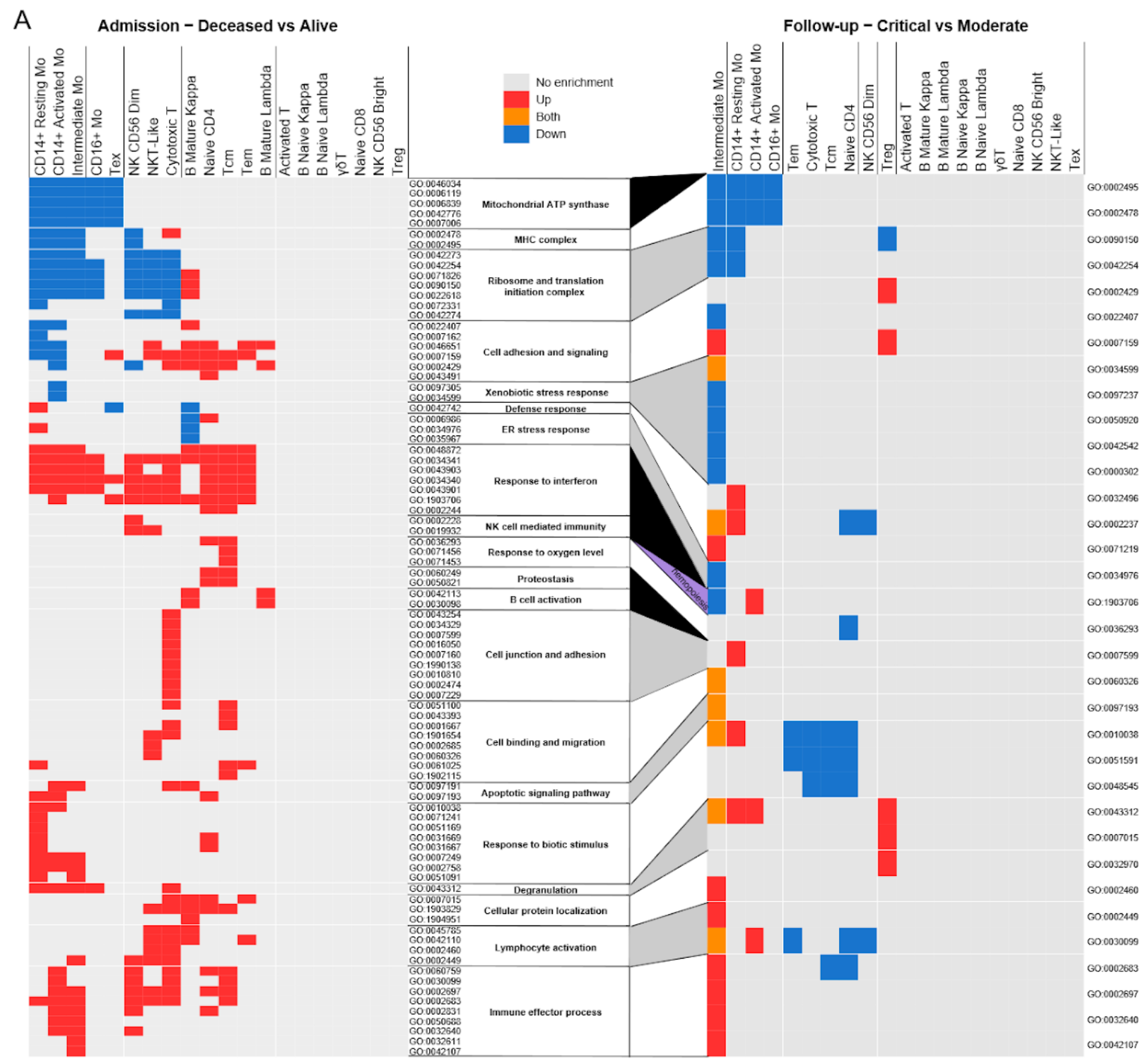

B

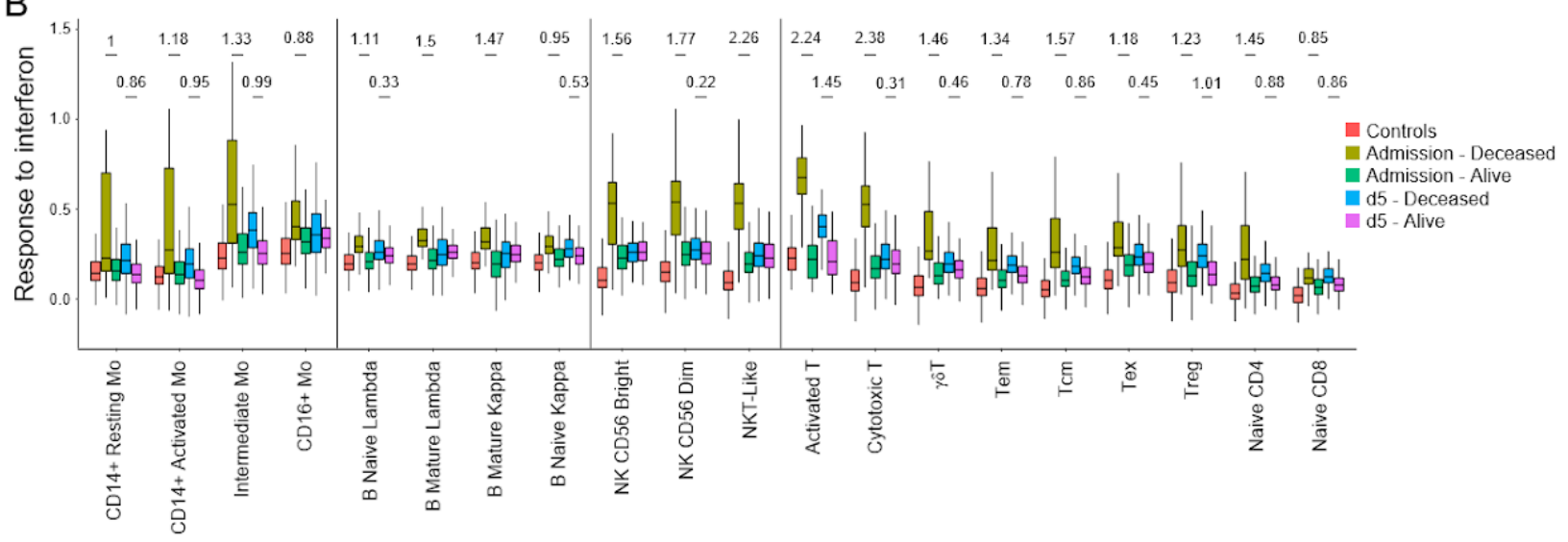

1269 Figure 3. Transcriptional variations in cell populations of severely ill COVID-19 patients 
medRxiv preprint doi: https://doi.org/10.1101/2021.09.14.21262309; this version posted September 22, 2021. The copyright holder for this preprint (which was not certified by peer review) is the author/funder, who has granted medRxiv a license to display the preprint in perpetuity.

It is made available under a CC-BY-ND 4.0 International license .

1270 (A) GO-term enrichment analysis for differentially expressed genes at admission between the "Deceased

1271 vs Alive" patient groups (left heatmap) and between the "Critical vs Moderate" COVID-19 patients at

1272 follow-up (right heatmap). Heatmap boxes are colored based on the enrichment observed for the

1273 hierarchical level 5 of the GO Biological-Process sub-ontology tree in the corresponding cell lineage:

1274 Grey for no significant enrichment; Blue, Red and Orange, respectively, for significant (q-value $<=0.05$ )

1275 enrichment of down-regulated, up-regulated and both up- and down-regulated genes. Cell population

1276 enrichment clusters have been generated using a complete-linkage clustering approach independently for

1277 both heatmaps resulting in a different order of lineages. GO categories only enriched at admission are

1278 highlighted in black between the two heatmaps, whereas the GO category highlighted in yellow

1279 (Hemopoiesis) represents the only category enriched only at follow-up. GO categories enriched at both

1280 admission and follow-up are successively highlighted in white and grey for easier visualization. (B)

1281 Evolution of the transcriptional expression for the Response to Interferon GO-term. Differentially

1282 expressed genes enriched in the GO-term in (A) were used to generate a Module Score representing the

1283 overall expression level for term genes in the cell lineage indicated at the bottom of the graph. Module

1284 scores shown were derived at admission and the day5 time-points for the "Deceased" and "Alive"

1285 COVID-19 patients separately. Control samples from healthy subjects are included as reference.

1286 Significance of differences between "Deceased" and "Alive" COVID-19 patients was tested by

1287 comparing the corresponding Module Score distribution in every cell subset using a Wilcoxon rank-test

1288 approach (q-value $<=0.05$ ). To provide a sample-size free evaluation of the difference in expression,

1289 Cohen's d effect size estimation is shown for every significant variation. Transcriptional evolution graphs

1290 for the other enriched GO categories are provided in Suppl. Figure S5. Tcm: Central memory T cells;

1291 Tem: Effector memory T cells; Tex: Exhausted T cells; Treg: Regulatory T cells; gdT: gamma delta T

1292 cells; B cells: either naive or memory cells expressing either the kappa or lambda light chain. 
medRxiv preprint doi: https://doi.org/10.1101/2021.09.14.21262309; this version posted September 22, 2021. The copyright holder for this preprint (which was not certified by peer review) is the author/funder, who has granted medRxiv a license to display the preprint in perpetuity.

It is made available under a CC-BY-ND 4.0 International license .

A
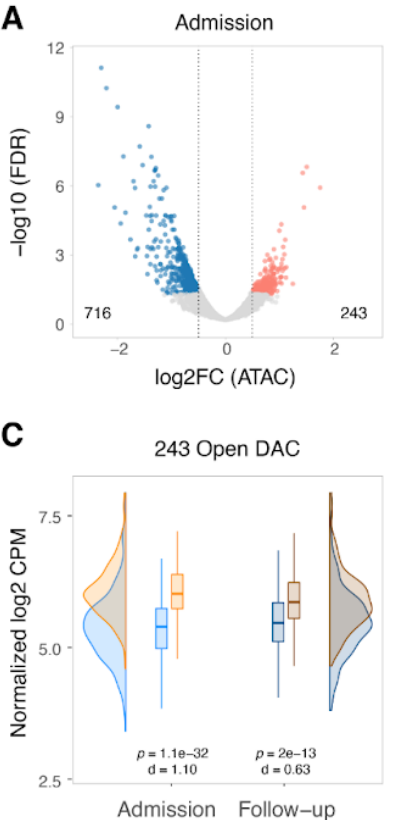
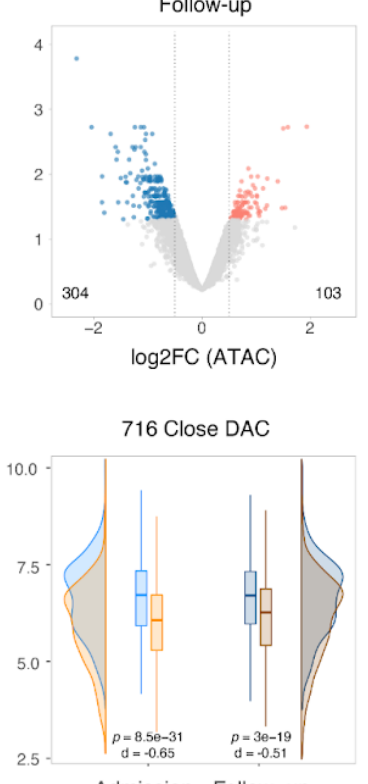

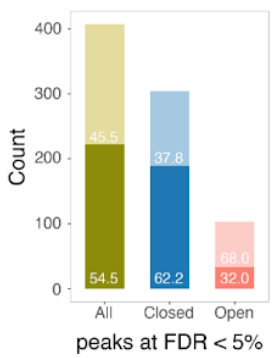

E
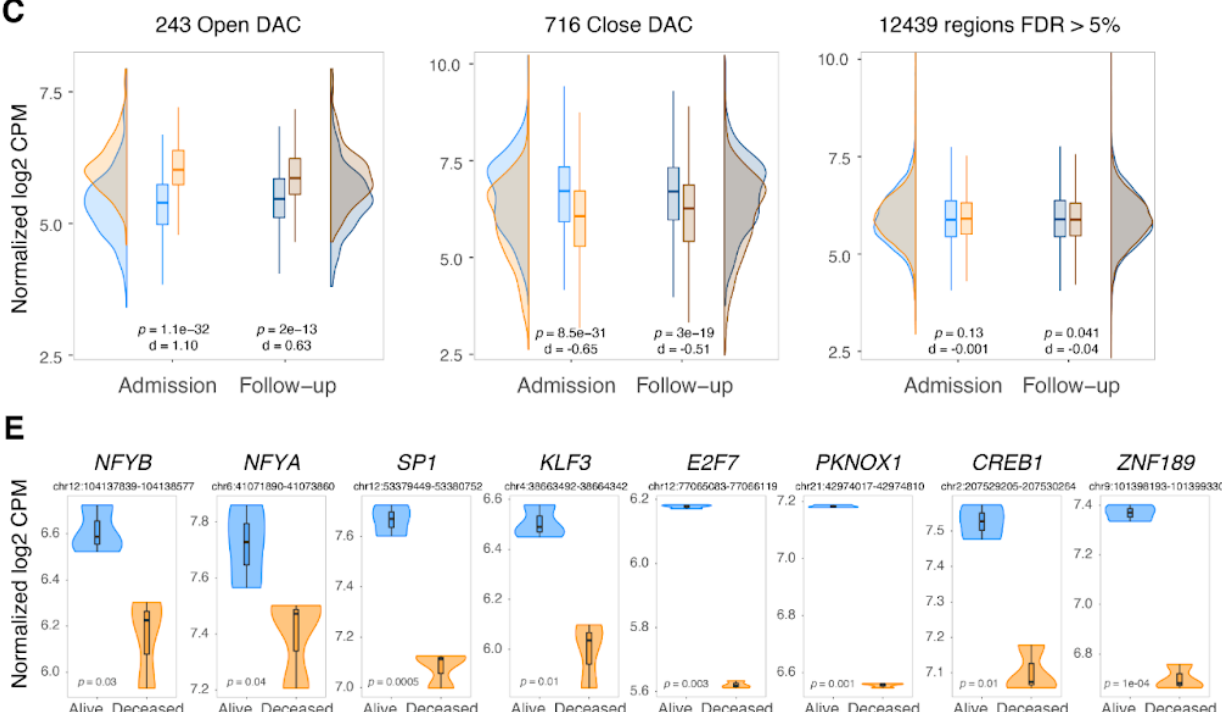

$\mathbf{F}$

Gene Ontology (biological process)

Reactome

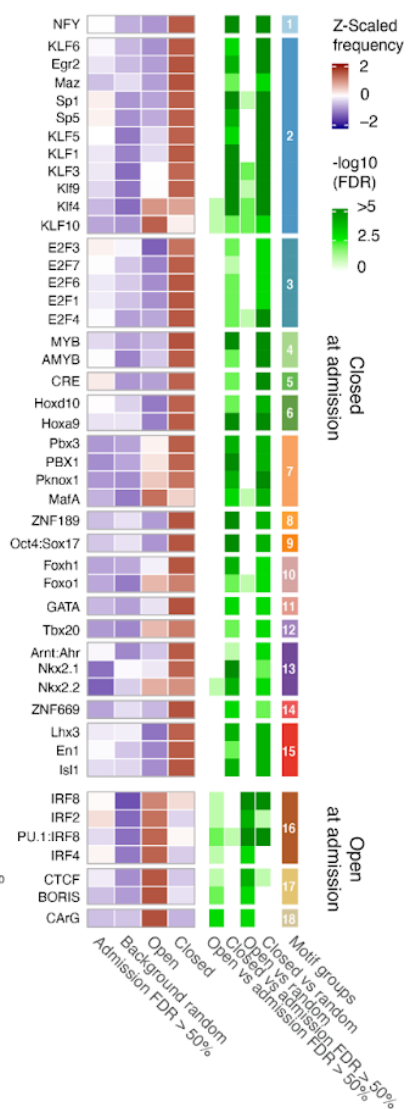

$$
\begin{array}{r}
\text { Closed at } A \\
2 \cdot \mathrm{Sp} \\
3 . \\
4 \cdot
\end{array}
$$
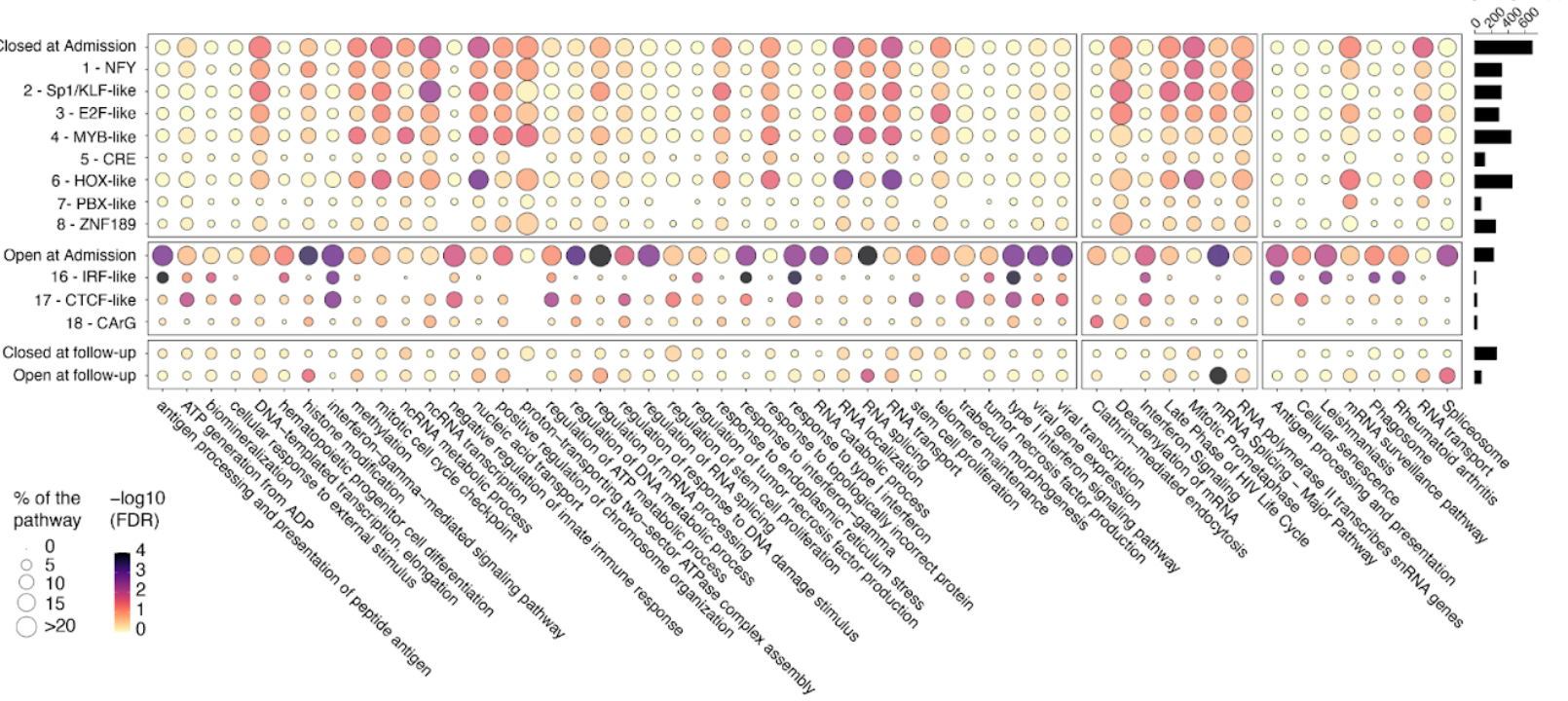

1294 Figure 4. Monocyte chromatin accessibility among COVID-19 patients. 
1295 (A) A total of 13,398 genomic regions identified as accessible by ATAC-seq were tested for differential 1296 accessible chromatin (DAC) and plotted according to their log2 fold change and corresponding adjusted $p$ 1297 value for the "Deceased vs Alive" comparison at day 0 and follow-up (days 5 and 15). More closed and 1298 more open chromatin regions in "Deceased" patients at a false discovery rate (FDR) $<5 \%$ and absolute $1299 \log 2$ fold change $(\log 2 \mathrm{FC})>0.5$ are shown in blue and red, respectively. (B) Intersection of DAC regions 1300 at admission and follow-up for the "Deceased vs Alive" group comparisons. The proportions of the 407 1301 significant DAC regions at follow-up that were also significant at d0 are shown in darker shade. The 1302 overlap for open DAC is indicated by the red bar while the overlap for closed DAC is indicated by the 1303 blue bar. (C) Plots indicating the distribution of chromatin states for regions significantly more open 1304 (left), more closed (center) and not significantly different at FDR > 5\% (right) for the "Deceased vs Alive" 1305 comparisons. The normalized $\log 2$ count per million (CPM) corresponding to accessibility levels for each 1306 of the chromatin regions denoted at the top was plotted in the y-axis and summarized as density and box 1307 plots for the admission and follow-up samples. Blue shading indicates the chromatin state for the "Alive" 1308 group and orange shading indicates the "Deceased" group. A Cohen's d value was used to estimate the 1309 effect size and a wilcoxon test to assess the significance of the differences of the distributions between the 1310 "Deceased" and "Alive" patient samples. (D) Motif enrichment analysis for 959 DAC regions between

1311 "Deceased vs Alive" at Admission. Of the 682 motifs tested, 46 were significantly enriched in DAC 1312 regions of deceased patients at FDR $<1 \%$ and are plotted as a heatmap. Of them, 39 motif groups were 1313 more frequently observed in DACs less accessible (Closed) in deceased patients, while seven motifs were 1314 observed more frequently in open DACs. A total of nine columns are identified at the bottom of the heat 1315 maps. The four columns on the left represent heatmaps of the Z-scaled motif frequency. The first two 1316 columns indicate motif frequencies in control groups including non-significant regions at FDR $>50 \%$ at 1317 admission and 50 thousand random genomic regions with the same length distribution as significant 1318 DACs, followed by open and closed DACs at admission. Shades of red indicate higher frequency and 1319 shades of blue lower frequency for each motif. The four columns at center of the heatmap indicate the 1320 negative $\log 10 \mathrm{FDR}$ of the enrichment for the motif shown in the first four columns. In the last column, 
medRxiv preprint doi: https://doi.org/10.1101/2021.09.14.21262309; this version posted September 22, 2021. The copyright holder for this preprint (which was not certified by peer review) is the author/funder, who has granted medRxiv a license to display the preprint in perpetuity.

It is made available under a CC-BY-ND 4.0 International license .

1321 transcription factors are grouped according to the homologies of their respective binding sites (details in

1322 Suppl. Figure 7). (E) Suppressed promoter accessibility in the "Deceased" patient group for eight TFs

1323 with motifs enriched in closed DAC regions at admission. Chromosomal locations of the peaks are shown

1324 below the TF name. Normalized $\log 2$ read counts (as counts per million, CPM) for promoter peaks are

1325 plotted on the y-axis for the "Deceased" and "Alive" groups. The corresponding chromatin tracks are

1326 shown in Suppl. Figure 8. (F) Gene ontology and pathway enrichment analyses for DAC regions at

1327 admission and follow-up (day 5 and 15) for the "Deceased vs Alive" contrast. Genes assigned to DAC

1328 regions (details in methods) or DACs stratified by motifs with most significant FDR p-values on Figure

$13294 \mathrm{D}$ were used to interrogate the KEGG and Reactome pathways, and the GO biological process terms

1330 databases. Non-redundant pathways and GO terms presenting an FDR $<5 \%$ and at least five genes in one

1331 of the tested conditions are plotted, with the bubble size representing the percentage of genes in a given

1332 pathway or term, and the colour shades indicating the negative log10 FDR. Representative examples of

1333 TF with enriched motifs in closed or open DAC regions are listed to the left of the graph. The number of

1334 DACs corresponding to each peak category on the left is shown as a bar plot on the right. 
medRxiv preprint doi: https://doi.org/10.1101/2021.09.14.21262309; this version posted September 22, 2021. The copyright holder for this preprint (which was not certified by peer review) is the author/funder, who has granted medRxiv a license to display the preprint in perpetuity.

It is made available under a CC-BY-ND 4.0 International license .
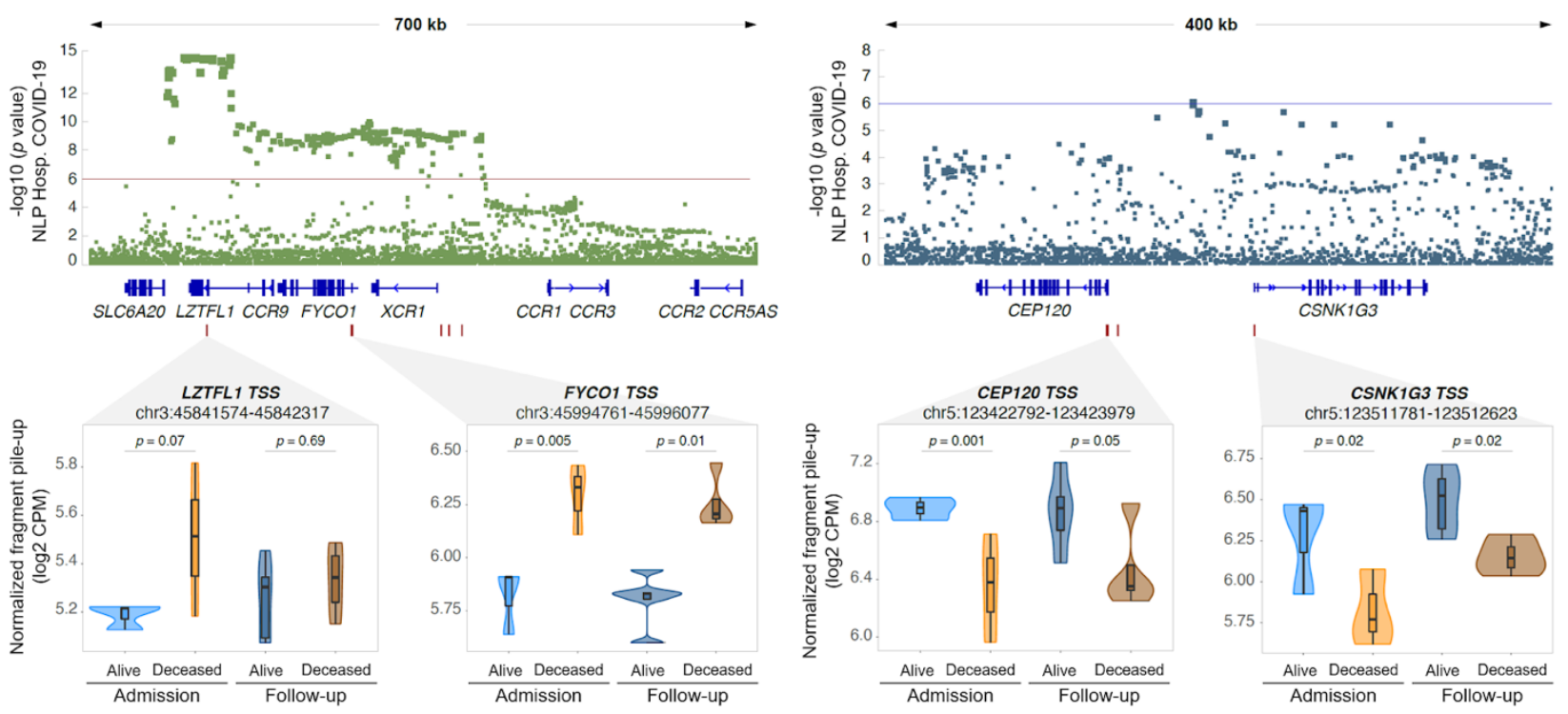

1336 Figure 5. Differential open chromatin at genes located within GWAS loci for COVID-19

1337 hospitalization.

1338 Two out of the five GWAS loci for severe COVID-19 with respiratory failure contain multiple DACs in

1339 monocytes from hospitalized COVID-19 patients (33). The y-axis indicates the evidence for association

1340 of SNPs (dots in the top panels) with severe COVID-19 as negative log10 p-value. The $\mathrm{x}$-axis indicates

1341 the chromosomal location of SNPs with colocalizing genes shown below. A zoom-in at the four regions

1342 with DAC for the "Deceased vs Alive" contrast is shown in the lower part of the figure. Box plots with

1343 normalized quantification of pileup fragments in peaks at promoter regions for "Deceased" and "Alive"

1344 are shown as $\log 2$ count per million (CPM) for patient groups at admission and follow-up. 
medRxiv preprint doi: https://doi.org/10.1101/2021.09.14.21262309; this version posted September 22, 2021. The copyright holder for this preprint (which was not certified by peer review) is the author/funder, who has granted medRxiv a license to display the preprint in perpetuity.

It is made available under a CC-BY-ND 4.0 International license .

A

C
B

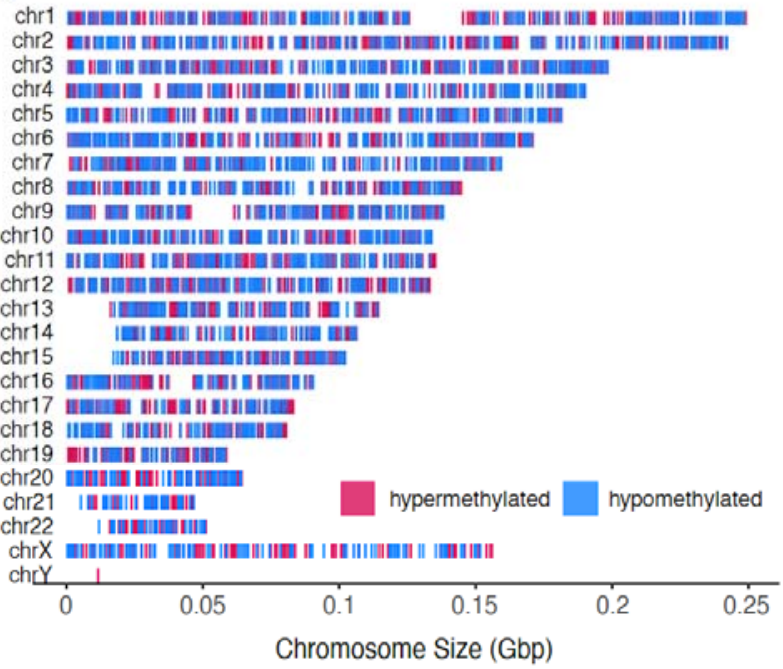

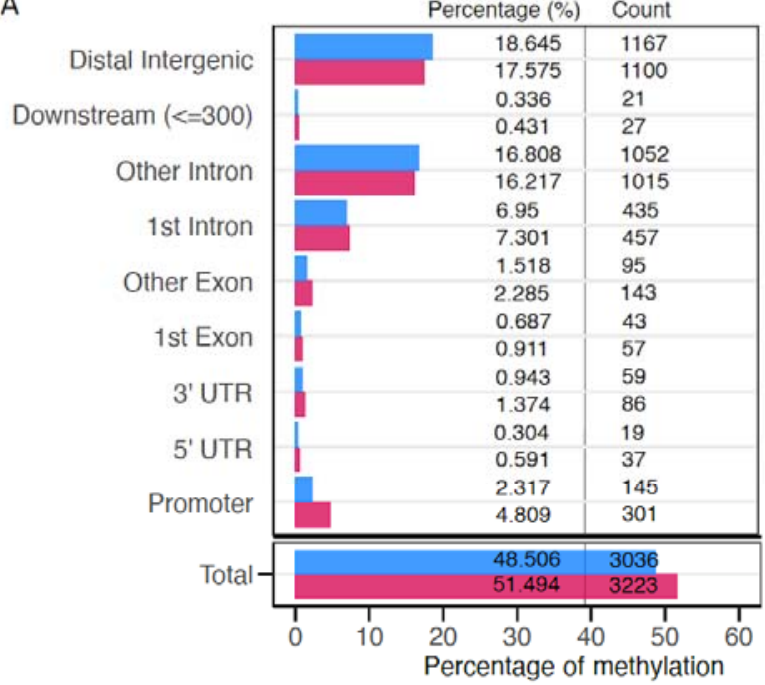
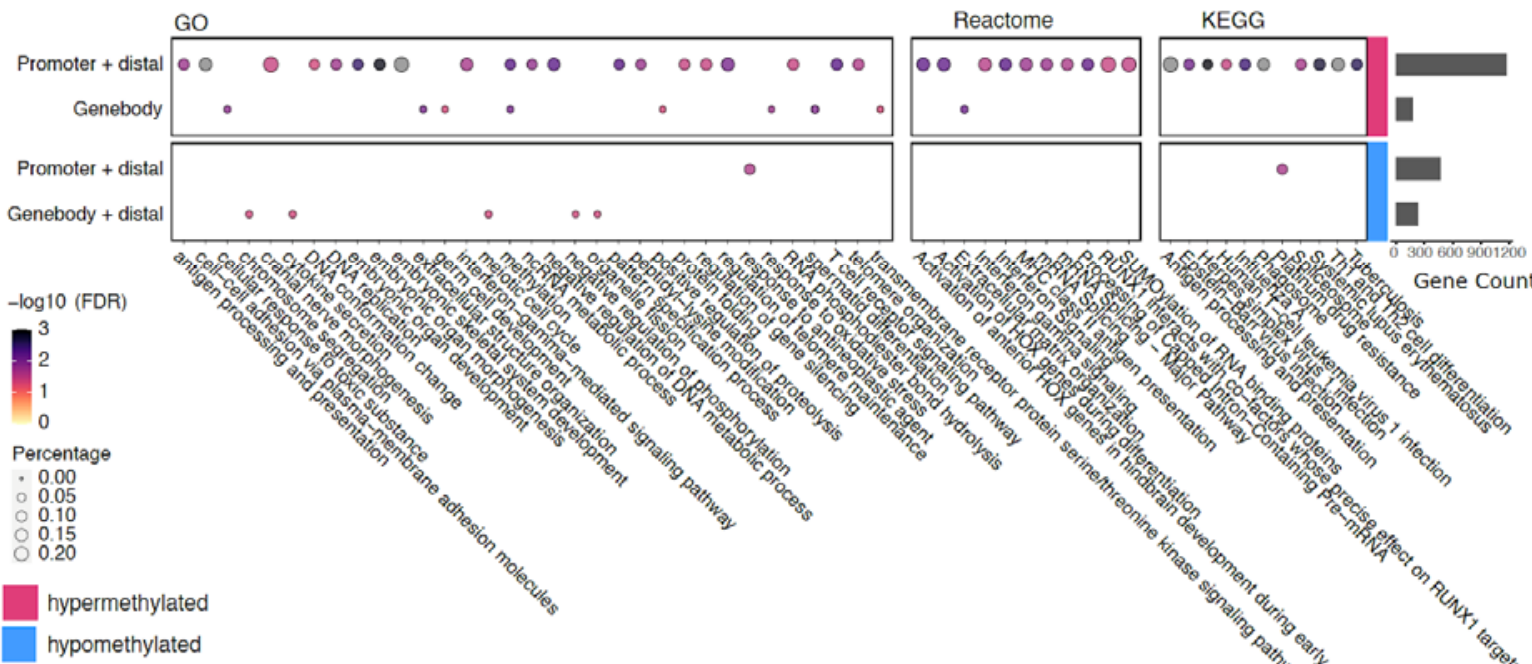
Gene Count
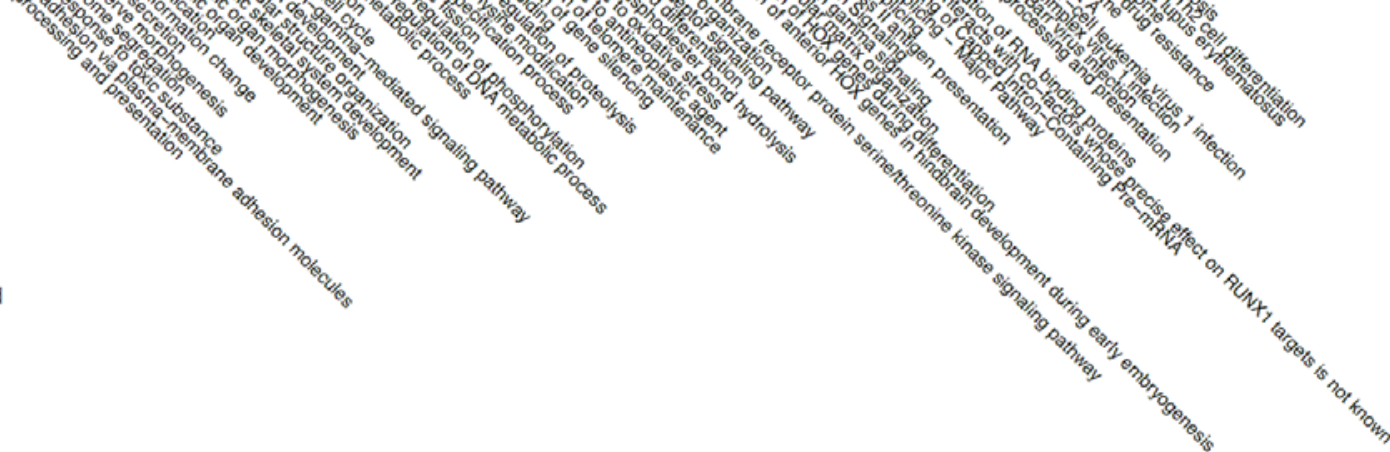

Figure 6. DNA methylation analysis of monocytes at admission.

1348 (A) Count and percentage of hyper (red) and hypo-methylated (blue) regions of Deceased vs Alive 1349 patients across annotated genomic regions. (B) Distribution of hyper- (red) and hypo-methylated (blue) regions across chromosomes. Each vertical line indicates a DMR. (C) Gene ontology and pathway enrichment analyses for DMRs at admission comparing "Deceased vs Alive" patients. Genes assigned to DMRs in promoters, gene bodies, and distal regions (details in method) were used to search the KEGG 
medRxiv preprint doi: https://doi.org/10.1101/2021.09.14.21262309; this version posted September 22, 2021. The copyright holder for this preprint (which was not certified by peer review) is the author/funder, who has granted medRxiv a license to display the preprint in perpetuity. It is made available under a CC-BY-ND 4.0 International license .

1355 Non-redundant pathways and GO terms showing FDR $<5 \%$ and with at least five unique genes and

1356 DMRs in one of the test conditions are plotted; bubble size represents the FDR and colour shading the 1357 percentage of genes with a corresponding significant DMR at FDR $<5 \%$. The total number of genes per 1358 group associated with DMRs used to interrogate the databases is shown in the bar plot on the right. 
medRxiv preprint doi: https://doi.org/10.1101/2021.09.14.21262309; this version posted September 22, 2021. The copyright holder for this preprint (which was not certified by peer review) is the author/funder, who has granted medRxiv a license to display the preprint in perpetuity.

It is made available under a CC-BY-ND 4.0 International license .

‘

C
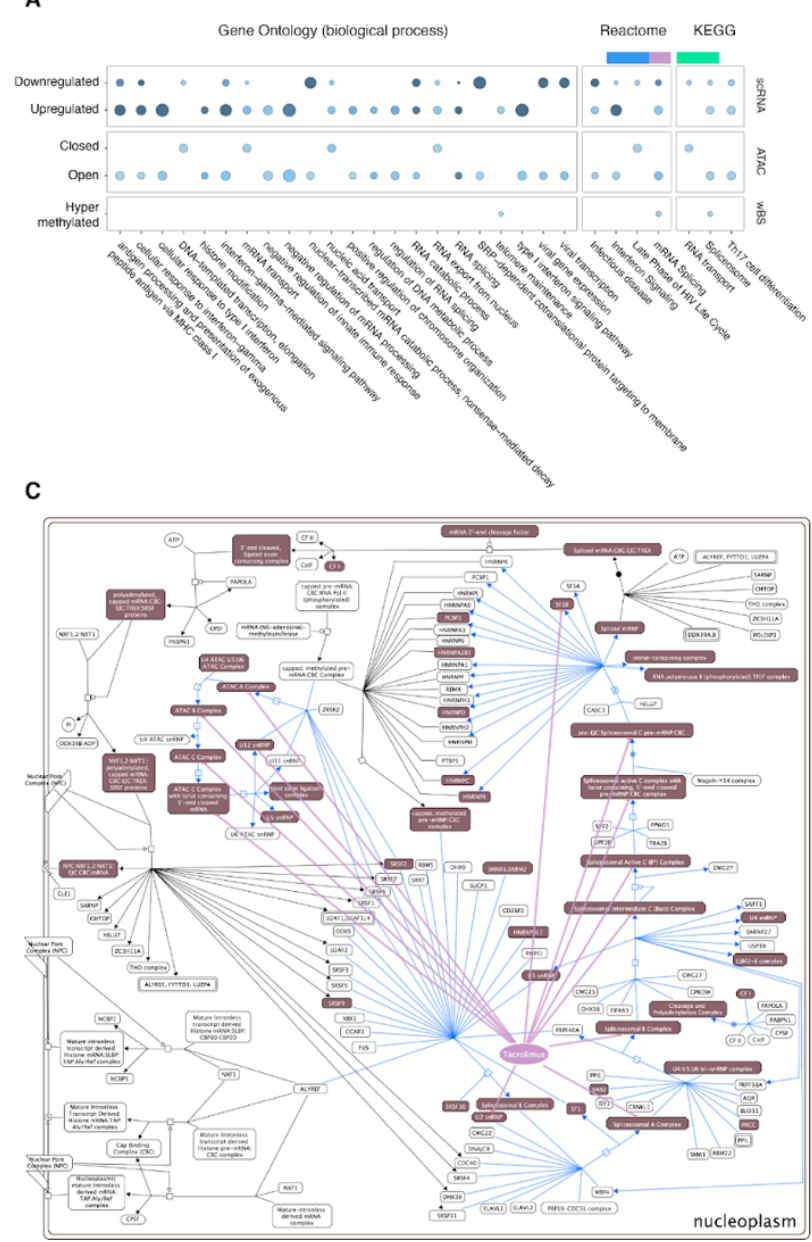

B
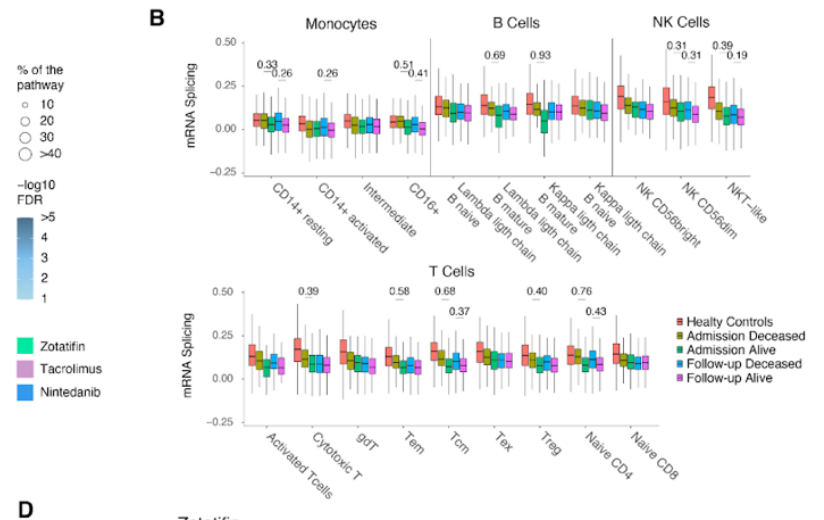

D
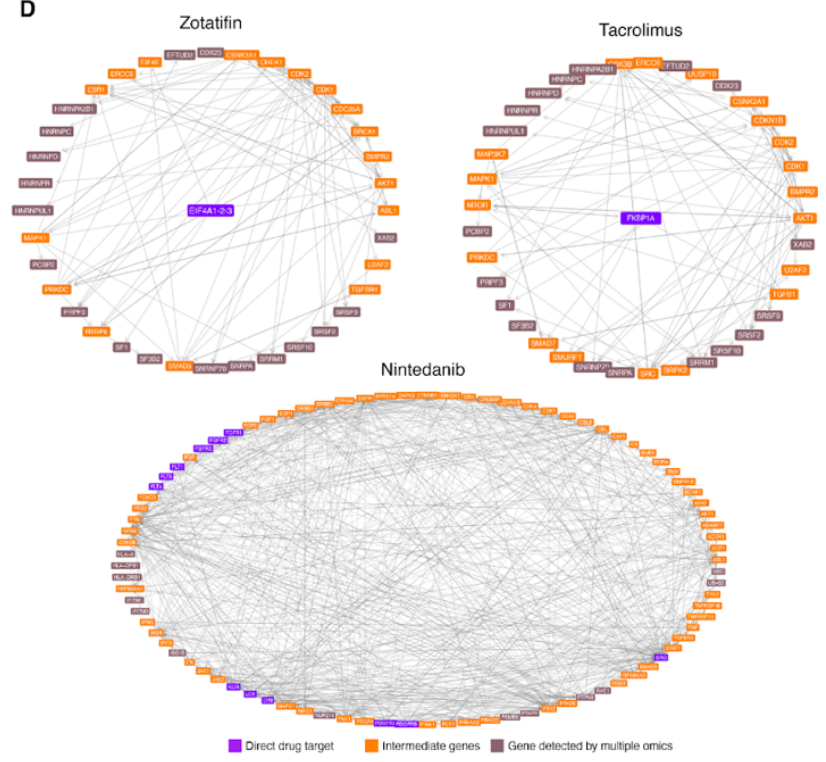

1361 Figure 7. Candidate drugs to treat hospitalized COVID-19 patients.

1362 (A) Pathways and GO biological process terms identified by differential transcriptomic, chromatin 1363 accessibility, and/or DNA methylation are shown in the bubble plot. The bubbles indicate pathways or 1364 terms with more than 10 genes with a FDR < 5\% (scRNA-seq and ATAC-seq) or FDR < 10\% (WGBS).

1365 Colour shades of the bubbles represent the $-\log 10(\mathrm{FDR})$ and the bubble size indicates the proportion of 1366 genes in the pathway or term that were significantly different between "Deceased" and "Alive" patient 1367 groups. The shared pathways and terms targeted by the Tacrolimus, Zotatifin, and Nintedanib drugs are 1368 shown at the top of the graph with colour shades corresponding to the drugs listed on the right of the 1369 graph. (B) Evolution of the transcriptional expression for the mRNA Splicing. Differentially expressed 1370 genes enriched in the Reactome's mRNA Splicing pathway were used to generate a Module Score 1371 representing the overall transcriptional expression level for the cell lineage indicated at the bottom of the 
medRxiv preprint doi: https://doi.org/10.1101/2021.09.14.21262309; this version posted September 22, 2021. The copyright holder for this preprint (which was not certified by peer review) is the author/funder, who has granted medRxiv a license to display the preprint in perpetuity.

It is made available under a CC-BY-ND 4.0 International license .

1372 graph. Module scores shown were derived at the D0 and D5 time-points. For each time point, the Module

1373 Score was estimated for the "Deceased" and "Alive" severely ill COVID-19 patients separately. Control

1374 samples from healthy subjects were included as reference for transcriptional expression levels.

1375 Significance of differences in the transcriptional expression levels between "Deceased" and "Alive"

1376 severely ill COVID-19 patients was tested by comparing the corresponding Module Score distribution in

1377 every group of cell subsets using a Wilcoxon rank-test approach (q-value <=0.05). To provide a sample-

1378 size free evaluation of the difference in expression, Cohen's d effect size estimation is shown for every

1379 significant variation observed. (C) Tacrolimus interacts with mRNA splicing hubs identified by

1380 significant transcriptomic and epigenetic changes between patients at admission who will succumb to

1381 COVID-19 and those who will recover. The mRNA splicing portion of the Processing of Capped Intron-

1382 Containing Pre-mRNA pathway is indicated by light blue lines. Genes and hubs tagged by both

1383 transcriptomic and epigenetic changes are highlighted by a brown shade. (D) Protein-protein interaction

1384 network targeted by candidate drugs. The proteins targeted by the candidate drugs were accessed in

1385 DrugBank and intersected with OmnipathR protein-protein interaction databases. Proteins targeted by the

1386 drugs (Zotatifin, Tacrolimus and Nintedanib) are shown in purple. The shortest interaction between

1387 protein drug targets to proteins encoded by genes identified by our study marked in brown via

1388 intermediate genes marked in orange are linked by light grey lines. For Zotatifin and Tacrolimus, proteins

1389 in the mRNA splicing pathway, and for Nintedanib proteins in the Interferon Signaling pathway identified

1390 in our study as significant DGE or DAC are shown in brown.

1391 